\title{
The Mythical Right to Obscurity: A Pragmatic Defense of No Privacy in Public ${ }^{\dagger}$
}

\section{HEIDI REAMER ANDERSON*}

\begin{abstract}
In several states, citizens who videotaped police misconduct and distributed the videos via the Internet recently were arrested for violating state wiretapping statutes. These arrests highlight a clash between two key interests-the public's desire to hold the officers accountable via exposure and the officers' desire to keep the information private. The arrests also raise an oft-debated privacy law question: When should something done or said in public nevertheless be legally protected as private?
\end{abstract}

For decades, the answer has been: "[T]here can be no privacy in that which is already public." However, given recent technological developments (e.g., cell phone cameras and YouTube), some scholars suggest that the law sometimes should restrict the exposure of truthful information shared in public. Like the police who claim to need privacy to do their job, these scholars claim that people need privacy in public in order to feel dignified and to feel comfortable developing new ideas. In their pragmatic balance, these privacy-related needs appear to trump exposure-related benefits.

In this Article, I argue that certain assumptions have led these scholars to overstate privacy-related harms and to

\footnotetext{
${ }^{\dagger}$ I owe many thanks to, among others, Thomas Anderson, Eric Goldman, Dennis Hirsch, Lyrissa Lidsky and the faculty who attended a workshop at the University of Florida for their helpful and encouraging comments on earlier drafts. I also wish to thank John Bennett and Barrett Rodriguez for their outstanding research assistance. All errors are my own.
}

* Assistant Professor, Florida Coastal School of Law. 
understate exposure-related benefits. After documenting and critiquing those assumptions, I show how the proper balance likely favors exposure over privacy in all but a few special cases. Ultimately, I conclude that the law should continue to protect the mass exposure of truthful yet embarrassing information via the "no privacy in public" rule. Otherwise, we risk sacrificing the many benefits of exposure-including those resulting from exposure of police misconduct-on the altar of a mythical right to obscurity.

\section{INTRODUCTION}

When it comes to privacy and accountability, people always demand the former for themselves and the latter for everyone else.

On June 14, 2010, police officer Ian Walsh attempted to detain two teenaged criminal suspects at a busy intersection in Seattle, Washington. ${ }^{2}$ While he was struggling with the first suspect, a second suspect pushed Officer Walsh's arms away from the first. ${ }^{3}$ Immediately, Officer Walsh swung and punched the second suspect directly in the face. ${ }^{4}$ The suspects were arrested and later released. 5

1 David Brin, The Transparent Society: Will Technology Force Us to Choose BETWEEN PRIVACY AND FREEDOM 1 (1998) (commenting on the proliferation of video surveillance). Justice Scalia once shared a similar sentiment regarding the conflict between people's desires for privacy and accountability, stating: "This law has every appearance of a prohibition that society is prepared to impose upon the press but not upon itself." Florida Star v. B.J.F., 491 U.S. 524, 542 (1989) (Scalia, J. concurring). In Florida Star, the Court held that a state law forbidding the reporting of a rape victim's name by mass media but not by individuals was unconstitutionally under-inclusive. 491 U.S. at 540 . Also commenting upon the conflict between privacy and accountability, privacy scholar Daniel Solove has acknowledged that "[p]rivacy impedes discourse, impairs autonomy in communication, and prevents accountability for one's conduct." Daniel J. Solove, The Virtues of Knowing Less, 53 DUKE L.J. 967, 973 (2003).

${ }^{2}$ Seattle Officer Punches Girl in Face During Jaywalking Stop, SEATTLE POSTINTELLIGENCER (June 15, 2010, 10:00 PM), http://www.seattlepi.com/local/article/Seattle-officer-punches-girl-in-face-during890218.php.

3 Id.

4 See Levi Pulkkinen \& Casey McNerthney, Police Punch Caught on Video Prompts Seattle Police Review of Arrest Procedures, SEATTLE POST-INTELLIGENCER (June 15, 2010, 10:00 PM), http://www.seattlepi.com/local/article/Punch-caught-on-video-prompts-Seattlepolice-889276.php (noting that "[w] hen another woman grabbed him, [the officer] punched her in the face"). The video clip, which includes some profanity, is available at http://www.youtube.com/watch?v=E9w9AfptGGQ. 
Had this confrontation occurred on June 14, 1980, instead of June 14,2010 , few people other than those present at the time would have learned about it or discussed it afterwards. If either teenager later shared their account with others, listeners may have doubted its veracity or have been skeptical about the events that occurred. In all likelihood, the confrontation would have become a story shared among few, and perhaps forgotten, but that is not what happened with this story. Instead, because the confrontation occurred in 2010, it was videotaped by a bystander who then posted the video online via YouTube. Anyone with an Internet connection then could find the video via a simple search engine query (e.g., "Seattle police punch"), and watch it repeatedly, on demand. ${ }^{6}$

The easily-retrieved Seattle video clip inspired many viewers to share their opinions online by writing comments to online news stories, by sharing opinions on blogs, by posting Facebook updates, or by Tweeting. ${ }^{7}$ These conversations about the incident addressed several important public policy issues, including: (i) racial tension (Officer Walsh was white, the suspects were African-American), (ii) sex discrimination (Officer Walsh was male, the suspects were female), and (iii) the government's police power versus the liberty of its citizens (the punch was viewed by many as excessive given the suspects' relatively minor offense of jaywalking). ${ }^{8}$ Similarly rigorous policy debates have occurred in multiple cities throughout the United

5 See Pulkkinen \& McNerthney, supra note 4 (documenting suspects' release).

${ }^{6} I d$. (reporting that video was recorded by a "bystander"). As of January 5,2011 , the "official" video posted on YouTube had over 1.7 million views. See Seattle Police Confrontation - komonews.com, YouTUBE (June 14, 2010),

http://www.youtube.com/watch?v=Egw9AfptGGQ\&feature=player_embedded.

7 The inner workings and appeals of these social networking sites have been well documented elsewhere. See, e.g., James Grimmelmann, Saving Facebook, 94 IOWA L. REv. 1137, 1142-49 (2009) (describing architecture of, and most common uses of, Facebook and MySpace); Paul M. Schwartz, Review: From Victorian Secrets to Cyberspace Shaming, 76 U. CHI. L. REV. 1407, 1447 (2009) (describing Twitter as "a microblogging service that allows its users to send and read other users' messages ... known as tweets, which are messages of no more than 140 characters in length.").

${ }^{8}$ Pulkkinen \& McNerthney, supra note 4 (reporting parties' gender and race and noting that the President of Seattle's Urban League "call[ed] the violent altercation an overreaction to jaywalking"); Casey McNerthney, Police Guild: Officer Did Nothing Wrong in Videotaped Punch, SEATTLE POST-INTELLIGENCER (June 14, 2010),

http://www.seattlepi.com/local/article/Police-guild-Officer-did-nothing-wrong-in885514.php (reporting police union president's opinion that Officer Walsh “did nothing wrong" and showing 234 written comments from June 15, 2010 to June 21, 2010). 
States in recent years, all triggered by violent police behavior exposed via "citizen journalism." 9

With each police exposure video, the public and government response generally proceeds in one of two directions. Some government officials react with a look inward, via internal investigations and, ultimately, changed policies. ${ }^{10}$ Others react by pointing the finger outward-at the one doing the videotaping. For example, in at least five states, citizens who videotaped police misconduct were prosecuted for violating eavesdropping and wiretapping laws, which bar recording conversations, absent consent of all parties, except when there is no reasonable expectation of privacy. ${ }^{11}$ In one notable example, a motorcyclist posted a video of his own roadside encounter with a plain-clothed, gun-wielding police officer who cited him for speeding. ${ }^{12}$ Shortly after the video received a

9 Only three months earlier, a different Seattle policeman was videotaped stomping on the head and body of a wrongly-apprehended Hispanic suspect while exclaiming, "I'm going to beat the [expletive] Mexican piss out of you, homey. You feel me?" FBI Investigating Seattle Police Beating, SEATTLE POST-INTELligencer (May 9, 2010, 10:00 PM), http://www.seattlepi.com/local/article/FBI-investigating-Seattle-police-beating890125.php. Perhaps the most infamous police brutality exposure in recent memory was the video depicting Bay Area Rapid Transit police Officer Johannes Mehserle shooting unarmed passenger Oscar Grant in the back. See John Cote, Police Kill Man Near Station Fruituale BART Station, S.F. CHRON., July 18, 2010 at C1, available at http://articles.sfgate.com/2010-07-18/bay-area/21988301_1_bart-police-bart-officersfruitvale-bart-station (recalling how "Grant was killed as he lay face down on the platform" and how "the shooting touched off widespread protests in Oakland . . . after a Los Angeles jury convicted Mehserle of involuntary manslaughter ... instead of a more serious murder charge"). A quick Google search for "police beating video" sadly reveals hundreds of such incidents in 2010. See Injustice Everywhere: The National Police Misconduct Statistics and Reporting Project, http://www.injusticeeverywhere.com (last visited Jan. 2, 2011) (maintaining "national police misconduct newsfeed" with summaries and links).

${ }^{10}$ For example, Seattle issued "Seattle Police Office of Professional Accountability" reports and "launched a global review of arrest tactics" after the Officer Walsh video surfaced. Police Guild, supra note 8.

${ }^{11}$ See Ray Sanchez, Growing Number of Prosecutions for Videotaping the Police, ABCNEWS.COM (July 19, 2010), http://abcnews.go.com/US/TheLaw/videotaping-copsarrest/story? id $=11179076$ (documenting arrests in Maryland, Florida, and New Hampshire); Wendy McElroy, Are Cameras the New Guns?, GrzmoDo (June 2, 2010, 5:00 PM), http://gizmodo.com/5553765/are-cameras-the-new-guns (documenting arrests in Illinois and Massachusetts and opining that "the prosecutions are a form of social control to discourage criticism of the police or simple dissent").

${ }_{12}$ See Sanchez, supra note 11; McElroy, supra note 11 (describing circumstances surrounding Anthony Graber's arrest). A Maryland Circuit Court judge later dismissed the charges against Mr. Graber. See Peter Hermann, Judge Says Man Within Rights to Record 
great number of views on YouTube, six state troopers showed up at the motorcyclist's home with a warrant, seized his computer, and later charged him with violating Maryland's anti-wiretapping statute; if convicted, he could face up to sixteen years in prison..$^{13}$

Arrests like these (i.e., arrests of those "caught" videotaping police), consequently have triggered their own privacy-themed debate. Because the threat of criminal prosecution for taping police acts as a censor, some commentators have called for states to more clearly permit such recordings and facilitate the public interest benefits they trigger. ${ }^{14}$ In opposition, police officers and their supporters argue that the threat of constant surveillance and later distribution via the Internet is an unfair invasion of privacy that prevents them from adequately doing their job. For example, officers may hesitate to take necessary action out of concern that a partial and possibly inaccurate video recording of that action will lead to the officers' firing or to bad police work. This concern, in turn, threatens the officers' reputation and public safety as a whole. ${ }^{15}$

Police Traffic Stop, BALT. SUn, September 27, 2010, at A1. Judge Plitt's opinion read, in part: "Those of us who are public officials and are entrusted with the power of the state are ultimately accountable to the public.... When we exercise that power in a public forum, we should not expect our activity to be shielded from public scrutiny." Id.

13 See MD. CodE ANN. § 10-402 (2000); Sanchez, supra note 11; McElroy, supra note 11 (describing circumstances surrounding Anthony Graber's arrest).

14 See Opinion, Our View on Cops and Cameras: When Citizens Film Police, It Shouldn't Be a Crime, USA TODAY, July 15, 2010, at A10; Sanchez, supra note 11 (quoting David Rocah, an attorney for the American Civil Liberties Union of Maryland, as stating, "The message is clearly, 'Don't criticize the police'.... With these charges, anyone who would even think to record the police is now justifiably in fear that they will also be criminally charged."); David Rittgers, Editorial, Maryland Wiretapping Law Needs an Update, BALT. SUN, June 1, 2010, at A13 (suggesting changes to Maryland law because threat of criminal prosecution is "enough to make citizens pause before pushing the record button"); H.R. Con. Res. 298, 111th Cong. (2010).

15 See Dennis J. Slocumb and Rich Roberts, Opinion, Opposing View On Cops and Cameras: Respect Officers' Rights, USA TODAY, Opinion, July 15, 2010, at 10A (opposing videotaping of officers in part because of "the inability of those with no understanding of police work to clearly and objectively interpret what they see"). In retort to this argument, one journalist responded: "If they're doing good police work, they should not be worried about getting caught on tape." Rittgers, supra note 14; cf. Daniel J. Solove, "I've Got Nothing to Hide" and Other Misunderstandings of Privacy, 44 SAN DIEGO L. REV. 745 (2007) (critiquing "nothing to hide" arguments like that of Rittgers). At least two police departments have decided to address the concern of incomplete footage by wearing cameras themselves. See BART Tests Police Cameras, S.F. CHRON., Sept. 30, 2011, http://www.signonsandiego.com/news/2011/sep/30/bart-tests-police-cameras (detailing plan of San Francisco's Bay Area Rapid Transit police to wear cameras); Lisa Halverstadt, Arizona Officers Wearing Video Cameras, THE ARIzONA REPUBLIC, Apr. 9, 2011, 
In many ways, the current debate over citizen exposures of public police conduct mirrors a broader exposure versus privacy debate among legal scholars: When should something done "in public" nevertheless be "private" and, thus, legally protected from exposure?16 Surprisingly, the combination of technologies that helped the Seattle police incident ignite such a useful debate-recording (small video camera), distribution (Internet/YouTube), and indexing (Google)-is the same combination that has led some privacy scholars to call for restricting the exposure and flow of truthful information shared in public. ${ }^{17}$ Their thesis is supported, in part, via anecdotal stories about persons exposed and the harm such persons suffered. ${ }^{18}$ Like the police

http://www.azcentral.com/news/articles/2011/04/09/20110409 police-camerarecordings.html (describing how police forces in Arizona will wear cameras in addition to using dashboard cameras).

${ }^{16}$ See, e.g., Solove, supra note 1 , at 969 (framing the question as, "When is it justifiable for the law to prohibit the disclosure of another person's private information?"); see generally Richard A. Posner, The Right to Privacy, 12 GA. L. REV. 393 (1978) (using economic theory to justify only a few circumstances in which one should be able to restrict the flow of accurate, personal information about one's self).

${ }_{17}$ See Neil M. Richards and Daniel J. Solove, Prosser's Privacy Law: A Mixed Legacy, 98 CALIF. L. REV. 1887, 1889 (2010) ("Today, the chorus of opinion is that the tort law of privacy has been ineffective, particularly in remedying the burgeoning collection, use and dissemination of personal information in the Information Age."); M. Ryan Calo, People Can Be So Fake: A New Dimension to Privacy and Technology Scholarship, 114 PENN ST. L. REv. 809, 817-824 (2010) (collecting other scholars' technology-based arguments for privacy regulation and concluding that "the notion that technology implicates privacy insofar as it augments the power to collect, process, or disseminate information dominates privacy and technology commentary"); Jacqueline D. Lipton, "We the Paparazzi:" Developing a Privacy Paradigm for Digital Video, 95 IOWA L. REV. 919, 927 (2010) (suggesting that " $[t]$ he fact that individuals can instantly snap a photograph ... and can then disseminate that image instantaneously and globally at the push of a button, raises significant problems"); Solove, supra note 1, at 970 (justifying the regulation of personal disclosures " $[\mathrm{g}]$ iven the development of technologies that permit extensive data gathering and dissemination"); DANIEL J. SOLOVE, UNDERSTANDING PRIVACY 101 (2009) [hereinafter, SOLOVE, UNDERSTANDING PRIVACY] ("New technologies have spawned a panoply of different privacy problems").

${ }^{18}$ See infra notes 104-17 and accompanying text; Lipton, supra note 17, at 921-22 (chronicling stories of Star Wars Kid and Dog Poop Girl as evidence of "worrying new trend" of "intruding into each other's privacy and anonymity with video and multimedia files in ways that harm the subjects of these digital files"); DANIEL J. SOLOVE, THE FUTURE OF REPUTATION: GOSSIP, RUMOR, AND PRIVACY ON THE INTERNET 38-48 (2007)

[hereinafter, SOLOVE, FUTURE OF REPUTATION] (documenting the "sobering consequences" of the online exposures of individuals known as Dooce, the Numa Numa dancer, Little Fatty, and Star Wars Kid). Implicit in some of these stories is a fear directive-that you, too, should be afraid of becoming Dog Poop Girl or her ilk. See infra notes 282-83 and accompanying text. 
who claim to need privacy to protect their reputations and do their job effectively, these scholars argue that people often need protection from exposure of what they do or say in public in order to feel wholly dignified and to feel comfortable developing new ideas. ${ }^{19}$

Although these scholars' primary goals-protection of individual dignity and individual "thinking space"-may be admirable, their attempts at balancing the costs and benefits of their proposed protections appear misplaced in at least two ways. First, they tend to overstate the potential privacy-related harms that result from exposure of information initially shared in public. ${ }^{20}$ Second, they frequently understate the many existing and potential benefits of exposing truthful information shared in public. ${ }^{21}$ After correcting for these errors, the revised pragmatic balance shared below indicates that the benefits of exposing public conduct likely outweigh the harms, even without directly invoking First Amendment speech rights. ${ }^{22}$ Accordingly, this Article concludes that the law should not restrict the collection and reporting of truthful information shared in public in order to prevent a perceived, potential harm to someone's privacy interests. ${ }^{23}$

Part I of this Article briefly defines the conflict between exposure and privacy. ${ }^{24}$ It also documents how the law previously has resolved that conflict through the "no privacy in public" rule. ${ }^{25}$ Part II reviews the position of other scholars that the "no privacy in public" rule is an

\footnotetext{
19 See SOlOVE, UNDERSTANDING PRIVACY, supra note 17, at 108 (noting how "persistent gawking can create feelings of anxiety and discomfort" that harm one's dignity); Eugene Volokh, Freedom of Speech and Information Privacy: The Troubling Implications of a Right to Stop People from Speaking about You, 52 STAN. L. REV. 1049, 1110-12 (2000) (chronicling other scholars' arguments for privacy restrictions on the basis that the disclosure "injures people's dignity or emotionally distresses them"); Neil M. Richards, Intellectual Privacy, 87 TEX. L. REV. 387, 412-16 (2008) (arguing that spatial privacy is necessary for thought development).
}

${ }^{20}$ See infra notes $173-214$ and accompanying text.

${ }^{21}$ See infra notes 217-267 and accompanying text.

${ }^{22}$ See infra Part III.C. Although some of the exposure-related harms and benefits I identify involve speech elements, and thus, the First Amendment interests of the speaker, one need not constitutionalize my arguments in order to make them persuasive.

23 See infra notes $279-83$ and accompanying text.

24 See infra notes $30-43$ and accompanying text.

25 See infra notes $44-89$. 
inadequate and antiquated rule that fails to protect obscurity. ${ }^{26}$ In Part III, this Article shows how these scholars' demand for a right to obscurity is misplaced because they (i) overstate the potential harms linked to more technologically-advanced and democratized exposure, and (ii) inadequately account for the many benefits of exposure that would be blocked should their quest for a right to obscurity succeed. ${ }^{27}$ Finally, in Part IV, this Article tentatively concludes that the benefits of the "no privacy in public" rule likely outweigh the privacy harms. ${ }^{28}$ Ultimately, changing the "no privacy in public" rule would risk sacrificing the many benefits of exposure-including those resulting from the exposure of police misconduct-on the altar of a mythical right to obscurity. ${ }^{29}$

\section{THE CONFLICT BETWEEN EXPOSURE AND OBSCURITY}

In this Part, I discuss the terminology and historical background necessary to appreciate the current debate over technology's alleged assault on obscurity. In Part I.A, I briefly define the terms exposure and privacy and characterize certain conflicts between the two as the "Obscurity Problem." Next, in Part I.B, I show how the law generally has resolved the Obscurity Problem through the simple "no privacy in public" rule. In later Parts, I demonstrate how this rule remains proper today, despite most pro-obscurity scholars' assertions to the contrary. ${ }^{30}$

\section{A. Defining the Obscurity Problem}

Generally, exposure occurs when one, without the express consent of the other: (i) lawfully gathers truthful information about another person or entity shared by the exposed person in public, and (ii) makes that information available to someone other than himself, often

\footnotetext{
${ }^{26}$ See infra notes $89-130$ and accompanying text.

${ }^{27}$ See infra notes 131-267 and accompanying text.

${ }^{28}$ Note, however, that there are special cases for which this balancing tips the other way. See infra Part III.D.

29 See supra notes 2-9 and accompanying text (equating calls for privacy in public to calls for a right to obscurity).

${ }^{30}$ See infra notes $111-138$ and accompanying text.
} 
in a context other than the one in which the information was shared. ${ }^{31}$ Exposure encompasses a broad range of actions, including an inperson recount to another of an event one witnessed earlier, a blog post about a speech recently given, and the surreptitious video recording of someone in public, later published to a website. As these few examples demonstrate, exposure can be helpful, neutral, or perhaps hurtful to the one exposed. ${ }^{32}$ If enough people pay attention to it and remember it, one effect of an exposure on the exposed person is to reduce his obscurity.33 Prior to the exposure, his words or actions were known only to a few; after the exposure, they are known to many. ${ }^{34}$ Ultimately, it is most helpful to view obscurity as the absence of exposure.

Viewing obscurity as the absence of exposure helps to better frame the current debate over the validity of the "no privacy in public" rule as a binary conflict of interests. 35 On one side, the side of exposure, are the benefits that flow immediately and in the long run from the general sharing of public information about people with each other; on the other side, the side of obscurity, are the harms prevented by

${ }^{31}$ For those familiar with Daniel J. Solove's privacy taxonomy, this definition incorporates, in part, the allegedly "harmful activities" of "information collection," "information processing," and "information dissemination." SOLOVE, UNDERSTANDING PRIVACY, supra note 17 , at 103 .

$3^{2}$ For example, the person exposed may view the in person recount as neutral gossip, the blog post about the speech as helpful publicity, and the surreptitious video recording as harmful to his dignity.

33 See Lior Jacob Strahilevitz, Reputation Nation: Law in an Era of Ubiquitous Personal Information, 102 Nw. U. L. REV. 1667, 1670 (2008) ("Personal information that was once obscure can be revealed almost instantaneously via a Google search."); see also SOLOVE, UNDERSTANDING PRIVACY, supra note 17, at 149 (quoting Aesop for the proposition that "[o]bscurity often brings safety").

34 See SOLOVE, FUTURE OF REPUTATION, supra note 18 , at 7 ("People who act inappropriately might not be able to escape into obscurity anymore; instead, they may be captured in pixels and plastered across the Internet.").

35 Focusing on the exposure versus privacy conflict also narrows the applicability of this Article's arguments to only those issues involving private citizens' exposure of public conduct, thus excluding those privacy issues involving other core interests. This category may be viewed as a subset of the "informational privacy" category. See Lior Jacob Strahilevitz, Reunifying Privacy, 98 CALIF. L. REV. 2007, 2010 (2010) (agreeing that "information privacy is a category with enough commonalities to render it a coherent concept") (citations omitted). 
protecting the same and similar information from exposure. ${ }^{36}$ Setting up the analysis in this "harms versus benefits" fashion also permits us to do the situational, problem-based harm analysis that at least one pro-pragmatism scholar, Daniel Solove, suggests is appropriate. ${ }^{37}$

In his book Understanding Privacy, Solove argues that the proper approach to addressing privacy concerns is to consider the interests involved in individual privacy problems. ${ }^{38}$ In this article, I accept Professor Solove's invitation to begin balancing harms and benefits in particular "problem situations" involving privacy. ${ }^{39}$ Specifically, I consider the harms and benefits of what I call the Obscurity Problem..$^{\circ}$ The Obscurity Problem occurs when a private actor (whom I and others describe as a "citizen journalist" 41 ) lawfully collects and further exposes information (spoken or behavioral) that someone else initially shared in public. ${ }^{22}$ Because any legal response to the

${ }^{36}$ Samuel Warren and Louis Brandeis described the natural conflict as follows: "Matters which men of the first class may justly contend, concern themselves alone, may in those of the second be the subject of legitimate interest to their fellow citizens." See Samuel D. Warren and Louis D. Brandeis, The Right to Privacy, 4 HARV. L. REV. 193, 215 (1890).

37 See Solove, Understanding PRIVACy, supra note 17, at 174; see also Danielle Keats Citron \& Leslie Meltzer Henry, Review: Visionary Pragmatism and the Value of Privacy in the Twenty-First Century, $108 \mathrm{MICH}$. L. REV. 1107 (2010) (reviewing and endorsing Solove's approach).

${ }^{8}$ See Solove, Understanding Privacy, supra note 17 , at 174.

$39 \mathrm{Id}$.

40 This problem would encompass, at least in part, the sub-problems Solove identifies as Identification, Disclosure, Accessibility and Distortion. SOLOVE, UNDERSTANDING PRIVACY, supra note 17, at 121-26 (identification), 140-46 (disclosure), 149-50 (increased accessibility), 158-61(distortion).

${ }^{41}$ See Randall D. Eliason, The Problems with the Reporter's Privilege, 57 AM. U.L. REV. 1341, 1366-67 (2008) (discussing "the rise of so-called citizen journalists" who "post information of public concern" via blogs, social networking sites and cable news sites). As Eliason further notes, CNN calls reports from citizen journalists "I-Reports" while Fox News calls similar reports "U-Reports." Id. at 1367 n.97; see also Jonathan Krim, Subway Fracas Escalates Into Test of the Internet's Power to Shame, WASH. POST, July 7, 2005, at Do1, available at http://www.washingtonpost.com/wp-

dyn/content/article/2005/07/06/AR2005070601953_pf.html (describing the Internet as "a venue of so-called citizen journalism, in which swarms of surfers mobilize to gather information on what the traditional media isn't covering, or is covering in a way that dissatisfies some people").

42 By definition, the Obscurity Problem excludes other related yet distinct privacy "problems," such as government surveillance or stalking, and only applies when the 
Obscurity Problem would involve changing the "no privacy in public" rule, the next section briefly chronicles the evolution of this rule as a way to resolve the Obscurity Problem. 43

\section{B. The "No Privacy IN Public" Rule}

The "no privacy in public" rule is tantalizing in its simplicity. Generally stated, it is: "[T]here can be no privacy in that which is already public." 44 The practical effect of the rule is that one has no tort law-protectable privacy interest (including a right to obscurity) in what one does or says in public. 45 This section begins with a brief overview of how this rule emerged in the late 19th century and how it developed through the mid-2oth century in both tort and criminal procedure contexts..$^{46}$ The overview illustrates how the rule's concept of "in public" was used initially as an adjective describing the nature of the person or information exposed, and later as an adjective describing the person's physical location. 47 Later sections of the

exposed person is the one who initially shared the information. For a discussion of how such problems are different from the Obscurity Problem, see Daniel Solove, A Taxonomy of Privacy, 154 U. PA. L. REV. 477 (2006).

43 See infra notes 44-88 and accompanying text. Part III shows how balancing harms and benefits supports retention of the "no privacy in public" rule.

44 Gill v. Hearst Pub. Co., 253 P.2d 441 (Cal. 1953). In Gill, the plaintiffs sued after Harper's Bazaar and related magazines published a photo of them in an "affectionate pose" at the Los Angeles Farmers' Market. Id. at 442. The court rejected plaintiffs' invasion of privacy claim because the photographed and published kiss took place "not ... on private grounds but rather ... in a public market place." Id. at 444. By "voluntarily expos[ing] themselves to public gaze in a pose open to the view of" others, the plaintiffs "waived their right of privacy." Id.

45 See Patricia Sanchez Abril, Recasting Privacy Torts in a Spaceless World, 21 HARV. J.L. \& TFCH. 1, 6 (2007) ("[C]ourts have generally held that anything capable of being viewed from a 'public place' does not fall within the privacy torts' protective umbrella."). As with any rule, there are exceptions in certain contexts, especially those involving property. For example, dropping one's unpublished manuscript in public does not mean that anyone can pick it up and print it without paying royalties any more than one could take one's house keys dropped in public and claim the house as one's own. Such extreme examples involve appropriation, in the former instance, and criminal breaking and entering, in the second, both of which fall outside the scope of this Article.

${ }^{46}$ See infra notes 61-88 and accompanying text.

47 See infra notes 54-60 and accompanying text; see also Abril, supra note 45, at 2 (using examples of gossip regarding drunken behavior to illustrate that "privacy is usually a 
Article will detail others' critiques of, and my defense of, the "no privacy in public" rule as it applies to the Obscurity Problem. ${ }^{48}$

\section{Public versus Private in The Right to Privacy}

Privacy first was identified as a common law right in Samuel Warren and Louis Brandeis's Harvard Law Review article, The Right to Privacy. ${ }^{49}$ Warren and Brandeis defined the right in various ways, including as the "right to be let alone" 50 and as the "right of determining .. . to what extent [one's] thoughts . . . shall be communicated to others." 51 Their widely reported, yet later questioned, motivation for writing the piece was a disdain for exposures that occurred after Warren's marriage to a New York socialite, and his associated loss in obscurity..$^{2}$ Ultimately, Warren and Brandeis called for a limited freedom from exposure of certain actions and information shared in public in order "to protect the privacy of private life."53

function of the physical space in which the purportedly private activity occurred, its subject matter, whether it was veiled in secrecy, and whether others were present").

${ }^{48}$ See infra Parts II and III.

49 Although the term "right to privacy" permeates legal and popular writings, many scholars have challenged the concept of privacy as a "right." See generally Diane L. Zimmerman, Requiem for a Heavyweight: A Farewell to Warren and Brandeis's Privacy Tort, 68 CORNELL L. REV. 291 (1983); see generally Volokh, supra note 19. Unlike this article, however, these critiques focus on the First Amendment as the primary justification for limiting privacy.

50 Warren \& Brandeis, supra note 36, at 195 (citing COOLEY ON TORTS, 2d ed., at 29).

51 Warren \& Brandeis, supra note 36 , at 198 (further suggesting that one "generally retains the power to fix the limits of the publicity which shall be given [his thoughts]"); Warren \& Brandeis, supra note 36 , at 198 n.2 ("It is certain every man has a right to keep his own sentiments, if he pleases. He has certainly a right to judge whether he will make them public, or commit them only to the sight of his friends.") (quoting Yates, J.).

${ }^{2}$ See Richards \& Solove, supra note 17, at 1897 n.59 ("Prosser believed that the press coverage surrounding the wedding of Warren's daughter had inspired the [Right to Privacy] article, although subsequent scholarship has proven that this could not actually have been the case.") (citations omitted).

53 Warren \& Brandeis, supra note 36 , at 215. 
Most relevant to the instant Article, Warren and Brandeis also attempted to define the types of information to which one's right to privacy did not extend, using a three-pronged public-versus-private distinction based on analogies to the common law of libel and slander, as well as French law.54 First, they stated that " $[t]$ he right to privacy does not prohibit any publication of matter which is of public or general interest." 55 This exclusionary statement used the word "public" as an adjective describing the nature of the information involved, regardless of the physical space in which the information was shared..$^{6}$ Next, Warren and Brandeis used "public" to describe the kind of individual involved, versus the nature of the information or its physical origin; inferring that the professional aspirations of the man himself determine whether the information about him is public or private. Specifically, they opined that information about one who seeks public office or position is "public," while the same kind of information about a person who seeks no such office or position would be "private." 57 Combining these first two prongs of Warren and

$54 \mathrm{Id}$. at $214-15$.

55 Id. at 214. Elsewhere in The Right to Privacy, Warren and Brandeis asserted that "the law must ... protect those persons with whose affairs the community has no legitimate concern" and "all persons, whatsoever their position or station" from having information "made public against their will." Id. at 214-15 (emphasis added).

${ }^{56}$ Solove, supra note 1 , at 1001 (describing Warren and Brandeis's public versus private distinction as a "newsworthiness test" based on whether a matter "is of public or general interest").

57 Warren \& Brandeis, supra note 36 , at 215 ("To publish of a modest and retiring individual that he suffers from an impediment in his speech or that he cannot spell correctly, is an unwarranted, if not an unexampled, infringement of his rights, while to state and comment on the same characteristics found in a would-be congressman could not be regarded as beyond the pale of propriety."); Warren \& Brandeis, supra note 36, at 215 ("Since, then, the propriety of publishing the very same facts may depend wholly upon the person concerning whom they are published, no fixed formula can be used to prohibit obnoxious publications."). This type of distinction appears to mirror the public figure versus private figure distinction in defamation law that lives on despite having been chipped away at via various rulings suggesting that whomever or whatever is worthy of press attention automatically loses private figure status. See New York Times Co. v. Sullivan, 376 U.S. 254, 279-80 (1964) (holding that public figure plaintiff must show that defamatory statement was made with "actual malice"); Gertz v. Robert Welch, Inc., 418 U.S. 323, 351 (1974) (distinguishing "all purpose" public figures, such as a current mayor, from "limited" purpose public figures, such as a crime victim); Solove, supra note 1, at 1008-10 (chronicling and critiquing the "public versus private figure" distinction); Christopher Russell Smith, Dragged into the Vortex: Reclaiming Private Plaintiffs' Interests in Limited Purpose Public Figure Doctrine, 89 IOWA L. REV. 1419, 1421 (2004) (suggesting that, under lower courts' recent applications of the public figure doctrine, "a 
Brandeis's private versus public distinction (the nature of the information and the aspirations of the person), one gets the following summation of the "no privacy in public" rule: "[T]he matters of which the publication should be repressed may be described as those which concern the private life, habits, acts and relations of an individual, and have no legitimate connection with his fitness for a public office which he seeks or for which he is suggested ... and have no legitimate relation to or bearing upon any act done by him in a public or quasipublic capacity." 58

Third, Warren and Brandeis briefly defined private versus public in the spatial sense, but only through a metaphor and without actual mention of the word "public." Specifically, they declared: "The common law has always recognized a man's house as his castle, impregnable, often, even to its own officers engaged in the execution of its commands. Shall the courts thus close the front entrance to constituted authority, and open wide the back door to idle or prurient curiosity?" 59 By referring to a "man's house as his castle," Warren and Brandeis appear to draw a line between what a man does within his own home and what he does outside of that particular zone of privacy. ${ }^{60}$ Interestingly, Warren and Brandeis did not mention this spatial sense of private versus public until the last few lines of their article, and, unlike the other two prongs of public versus private, they mentioned it without citation to any source. Thus, Warren and Brandeis acknowledged the value in exposure of certain information shared in public, yet they yearned for additional legal protection for

private plaintiff may be found to be a public figure even though he or she has little or no involvement in [a] controversy").

${ }^{8}$ Warren \& Brandeis, supra note 36 , at 216.

59 Id. at 220.

${ }^{60}$ The concept of a man's home as his castle-and, thus, a place worthy of protection from intrusion by the government and private individuals-often is referred to as the Castle Doctrine. The Castle Doctrine has been used in various contexts, including cases involving Fourth Amendment search and seizure issues, homicide cases involving self-defense, and privacy cases. Many trace the origin of the Castle Doctrine to English Common Law, and, more specifically, to Sir Edward Coke in Semayne's Case. See Nicholas J. Johnson, SelfDefense?, 2 J.L. ECON. POL'Y 187, 199 (2006). In Semayne's Case, Lord Coke stated, "For a man's house is his castle, \& domus sua cuique est tutissimum refugium; for where shall a man be safe, if it be not in his house?" See David I. Caplan \& Sue Wimmershoff-Caplan, Postmodernism and the Model Penal Code $v$. the Fourth, Fifth and Fourteenth Amendments and the Castle Privacy Doctrine in the Twenty-First Century, 73 UMKC L. REV. 1073, 1090 (2005) (citations omitted). 
some information and actions shared in public.61 For them, the "public" part of the "no privacy in public" distinction referred to the person, to the nature of the information about the person, and to the person's physical location when the information was shared.

\section{Public Versus Private in Prosser's Privacy Torts ${ }^{62}$}

In the many decisions and voluminous commentary to follow Warren and Brandeis's article, no person was more influential than William Prosser, primarily through his treatise, Handbook on the Law of Torts, and his 1960 California Law Review article, Privacy. ${ }^{63}$ In these and other works, Prosser shaped a disorganized set of privacyrelated cases into four tort-based causes of action one could use to protect the right to privacy defined by Warren and Brandeis. ${ }^{64}$ The four torts included: (i) intrusion upon the plaintiff's seclusion, (ii) public disclosure of embarrassing private facts, (iii) false light publicity, and (iv) appropriation. ${ }^{65}$ The Restatement of Torts, with Prosser as its chief reporter, adopted this four-pronged approach to

${ }^{61}$ At least one scholar has suggested that, at its core, Warren and Brandeis's binary distinction between the public and the private was a distinction between conduct or spaces associated with men, which were considered public, and those more traditionally associated with women, which made up the private sphere. See Neil M. Richards, The Puzzle of Brandeis, Privacy, and Speech, 63 VAND. L. REV. 1295, 1304-05 (2010).

62 Although this article focuses on the four privacy torts originally crafted by William Prosser, other torts also involve privacy interests. See Solove, supra note 1, at 971-73 (noting torts such as breach of confidentiality for disclosures by physicians and banks as well as statutory restrictions on the disclosure of certain records).

63 See William L. Prosser, Handbook of the LaW of TorTs (1st ed. 1941) [hereinafter Prosser, HandBook]; William L. Prosser, Privacy, 48 Calif. L. Rev. 383 (1960) [hereinafter Prosser, Privacy]; see also Richards \& Solove, supra note 17, at 1888 (anointing Prosser as "privacy law's chief architect"); see also Richards \& Solove, supra note 17, at 1903-12 (chronicling history of Prosser's "influence over the development of tort privacy").

64 See Richards \& Solove, supra note 17, at 1888 (noting that Prosser "was engaged with tort privacy throughout his career, from his earliest torts scholarship in the 1940 os until his death in 1972"). In the sixty years preceding his article, privacy as a tort theory had struggled to develop, being limited at first to commercial uses of persons' likenesses without permission and a handful of state statutes purporting to protect additional uses as well. See Richards \& Solove, supra note 17, at 1893-95 (citations omitted).

65 Prosser, Privacy, supra note 63, at 389 . Prosser's efforts have been characterized as "tak[ing] a mess of hundreds of conflicting cases and reduc[ing] them to a scheme of four related but distinct tort actions." Richards \& Solove, supra note 17, at 1889. 
privacy; courts and legislatures implemented it as well. ${ }^{66}$ All of these sources of law reflect, to some degree, Prosser's own skepticism about the coherence, wisdom and utility of the privacy torts. ${ }^{67}$ This skepticism, in turn, stunted the torts' growth and prevented them from evolving to clearly cover more modern privacy concerns. ${ }^{68}$

Prosser's primary concern about the reach of these torts was that they provided "a power of censorship over what the public may be permitted to read, extending very much beyond that which they have always had under the law of defamation." 69 In particular, he was concerned about the privacy torts' potential to restrict the press. $7^{70}$ Given this concern over restricting the public's access to truthful information, Prosser "sought to limit [his privacy torts'] capacity for growth" and succeeded..$^{71}$ One specific tactic he used to purposefully stunt the growth of his own creations was to emphasize the "no privacy in pubiic" distinction in the torts' elements and their suggested applications.

Prosser's use of the public versus private dichotomy at first appears to model that of Warren and Brandeis's first and second prongs discussed above. In his handbook, Prosser states that none of the privacy torts restricts or punishes the publication of information "of public interest of a legitimate character." 72 This statement, like that of Warren and Brandeis, uses the word public to describe the nature of the information and perhaps the identity of the person-and not the

${ }^{66}$ Richards \& Solove, supra note 17 , at 1904.

${ }^{67} \mathrm{Id}$. at $1906-07$.

${ }^{68} I d$.

${ }^{69}$ See id. at 1900 (quoting Prosser, Privacy, supra note 63, at 423).

70 See id. at 1897-98 (citing Prosser, Privacy, supra note 63, at 410).

${ }^{71}$ See id. at 1905-07. G. Edward White concisely summarized the Prosser-led progression as follows: "A classification made seemingly for convenience (1941) had been expanded and refined (1955), hardened and solidified (1960 and 1964, when the 'common features' of privacy were declared), and finally made synonymous with 'law' (1971). Prosser's capacity for synthesis had become a capacity to create doctrine. One began an analysis of tort privacy by stating that it consisted of 'a complex of four wrongs,' and implicitly, only those wrongs." See G. EDWARD WHITE, TORT LAW IN AMERICA: AN INTELLECTUAL HISTORY 176 (expanded ed. 2003) (quoted in Richards \& Solove, supra note 17, at 1905).

72 See Prosser, HANDBooK, supra note 63, at 1050 (cited in Richards \& Solove, supra note 17 , at 1897). 
physical space in which the information is shared.73 However, Prosser, in a possible deviation from Warren and Brandeis, effectively neutralizes other privacy torts by repeatedly using "public" in the spatial sense. This is most pronounced in the publicity to private facts tort, which suggests no liability "when the defendant merely gives further publicity to information about the plaintiff that is already public" or for "what the plaintiff himself leaves open to the public eye." 74 Similarly, in the intrusion upon seclusion tort, an invasion of one's personal physical area, or its equivalent, is required. 75 Implicit in this element is that there must be some legitimately secluded space in which the other party is intruding-a private, versus public, space. Under the Restatement, one only has an intrusion claim if the intrusion occurs in the home or other traditionally secluded place, such as a hotel room. ${ }^{76}$ The spatial part of the private versus public distinction also is evident in the voluminous cases interpreting the intrusion and other privacy torts which both preceded and followed Prosser's Privacy. ${ }^{77}$ Ultimately, Prosser's version of the public versus

73 See supra notes 54-57 and accompanying text (documenting Warren and Brandeis's approaches to the public versus private distinction).

74 See RESTATEMENT (SECOND) OF TORTS $§ 652 \mathrm{D} \mathrm{cmt.} \mathrm{b} \mathrm{(1977).}$

75 See id. at $\S 652$ B (1977); see also Stien v. Marriott Ownership Reports, Inc., 944 P.2d 374 (Utah Ct. App. 2007) (rejecting invasion of privacy claim based on video footage of employees later shown at company party).

${ }^{76}$ See RESTATEMENT (SECOND) OF TORTS $\S 652 \mathrm{D} \mathrm{cmt.} \mathrm{b} \mathrm{(1977)} \mathrm{(suggesting} \mathrm{that} \mathrm{invasion}$ may be by physical intrusion into hotel room or home or other examination such as of one's mail, wallet, or bank account); id. at cmt. c ("Nor is there liability for observing him or even taking his photograph while he is walking on the public highway."); id. at illus. 6-7 (distinguishing drunken behavior on public street from having one's skirt blown over her head to reveal underwear).

77 See SOlOVE, UNDERSTANDING PRIVACY, supra note 17, at 164 (2008) ("U.S. courts recognize intrusion-upon-seclusion tort actions only when a person is at home or in a secluded place. This approach is akin to courts recognizing a harm in surveillance only when it is conducted in private, not in public."); see also Lyrissa Barnett Lidsky, Prying, Spying and Lying: Intrusive Newsgathering and What the Law Should Do About It, 73 TUL. L. REV. 173, 204 (1998) ("Intrusion is designed to protect an individual's sphere of privacy, whether spatial or psychological ...."). Prosser's influence on case law is welldocumented; thus, the many privacy tort cases need not be further re-examined here. Rather, it is sufficient to note that the private versus public distinction also is evident in the cases interpreting Prosser's torts. See Richards \& Solove, supra note 17, at 1906 ("Based on our familiarity with several hundred privacy tort cases from the 1960 s to the present, the overwhelming majority of courts have adopted wholesale the specific language of either the Restatement or Prosser's other works in defining the privacy torts."); SOLOVE, UNDERSTANDING PRIVACY 161-62, 164 (reviewing cases). 
private distinction's effect on the privacy torts, as reflected in the Restatement, is as follows: "There is no liability when the defendant merely gives further publicity to information about the plaintiff which is already public." 78

\section{Public versus Private in Fourth Amendment Cases}

Perhaps the clearest and most familiar application of the public versus private distinction in the spatial sense is in criminal search and seizure cases.79 In its simplest form, the Fourth Amendment's exclusionary rule blocks the use of evidence obtained during a warrantless search of an area in which the defendant had both a subjective expectation of, and an objectively reasonable expectation of, privacy ${ }^{80}$ In determining whether one's expectation of privacy is objectively reasonable, the Supreme Court has said that "in the home, our cases show, all details are intimate details, because the entire area is held safe from prying government eyes." 81 Thus, one focus of the reasonableness inquiry is on the location in which the search was conducted and, more specifically, its proximity to the defendant's

\footnotetext{
78 See ReSTATEMENT (SECOND) OF TORTS $§ 652 \mathrm{D} \mathrm{cmt}$. c. (1977). However, as acknowledged in Part III.D, exposures of certain aspects of a person, even if captured in public, likely involve a different balance of interests and thus are less worthy of protection. See infra notes 272-78 and accompanying text; see RESTATEMENT (SECOND) OF TORTS §652B, cmt. c (1977) ("Even in a public place, however, there may be some matters about the plaintiff, such as his underwear or lack of it, that are not exhibited to the public gaze; and there may still be invasion of privacy when there is intrusion upon these matters.").

79 This emphasis on spatial privacy in search and seizure cases is understandable given that the text of the Fourth Amendment uses the word "houses." U.S. CONST. amend. IV ("The right of the people to be secure in their persons, houses, papers and effects, against unreasonable searches and seizures, shall not be violated ....").
}

80 See Katz v. U.S., 389 U.S. 347 (1967). In order to be protected from a warrantless search under the exclusionary rule, one must pass Katz's two-part test: (i) the person must "[first] have exhibited an actual (subjective) expectation of privacy, and (ii) "second, ... the expectation [must] be one that society is prepared to recognize as 'reasonable." Id. at 361 (Harlan, J., concurring). The practical effect of the Katz decision was to require the government to obtain a warrant before wiretapping a phone and recording the content of conversations.

${ }^{81}$ See Kyllo v. United States, 533 U.S. 27, 37 (2001); see also United States v. Dunn, 480 U.S. 294, 300 (1987) ("[T] he Fourth Amendment protects the curtilage of a house and that the extent of the curtilage is determined by ... whether the area harbors the "intimate activity associated with the sanctity of a man's home and the privacies of life.") (internal quotations omitted). 
home. ${ }^{82}$ Even a search of one's home by electronic means may be deemed to invade someone's reasonable expectation of privacy in a physical space. ${ }^{83}$ Ultimately, if the government conducts a warrantless search of a person's private space-most often, his home-then the evidence obtained in that search cannot be used because the person had a reasonable expectation of privacy in such space. ${ }^{84}$

As the search location moves away from the inside of one's home, the objective reasonableness of the privacy expectation becomes more remote. ${ }^{85}$ For example, the Supreme Court has endorsed warrantless searches of one's property from an aircraft in public air space and of one's garbage bags placed at the curb. ${ }^{86}$ This is because as the search moves away from a person's home, it becomes more likely that the person has voluntarily consented to having the information made available to others. ${ }^{87}$

${ }^{82}$ See Payton v. New York, 445 U.S. 573, 590 (1980) ("[T] he Fourth Amendment has drawn a firm line at the entrance to the house."). Although it is true that the Katz majority declared that "the Fourth Amendment protects people, not places," Katz, 389 U.S. at 351, "what protection it affords to those people ... generally ... requires reference to a "place." $I d$. at 361 (Harlan, J., concurring). In other words, whether one's expectation of privacy is deemed "reasonable" often depends in large part upon where one was located at the time and how much that place was like one's home. See Dunn, 480 U.S. at 334-35. For a recent and thorough critique of the Supreme Court's focus on the home and one's proximity thereto in determining the scope of one's Fourth Amendment rights, see Stephanie M. Stern, The Inviolate Home: Housing Exceptionalism in the Fourth Amendment, 95 CORNELL L. REV. 905 (2010).

${ }^{8}$ See, e.g., Kyllo, 533 U.S. at 34-35 (finding that authorities' warrantless use of heatsensing technology not in general public use to obtain information about the inside of defendant's home invaded his reasonable expectation of privacy).

84 However, even items within one's home or office are not necessarily protected if one exposes them to the public. See California v. Ciraolo, 476 U.S. 207, 213 (1986) (quoting Katz, 389 U.S. at 351).

85 The four factors to be used to determine whether a space falls within a home's "curtilage," and thus is entitled to heightened Fourth Amendment protection, are: "(1) the proximity of the area to the home; (2) whether the area is within an enclosure surrounding the home; (3) the nature and uses to which the area is put; and (4) the steps taken by the resident to protect the area from observation by passersby." Dunn, 480 U.S. at 1139 (finding that barn was not part of home's curtilage in part because it was not used for intimate activities).

${ }^{86}$ See Florida v. Riley, 488 U.S. 445 (1989) (police examination of partially-open greenhouse from aircraft in navigable airspace was not a search that violated defendant's reasonable expectation of privacy); California v. Greenwood, 486 U.S. 35, 36-37 (1988).

${ }^{87}$ See Greenwood, 486 U.S. at 39 (reasoning that defendants had no expectation of privacy in their garbage bags placed at the curb in part because such bags "left on or at the side of a 
The Supreme Court also has stated that no one has a reasonable expectation of privacy in something done in "plain view" or in an "open field." 88 Similarly, under the third party doctrine, sharing information with a third party defeats later claims to privacy in that information. ${ }^{89}$ For example, one has no reasonable expectation of privacy in an email after it is delivered to its intended recipient. $9^{\circ}$ Nor does one have a reasonable expectation of privacy in the numbers one dials by phone, given that those numbers were shared with someone else-the phone company. ${ }^{91}$ Thus, if the conduct or information was shared in a public or quasi-public place or even with someone else in a private place, then it most likely could be collected and used against a defendant because he has no reasonable expectation of privacy in something shared in public. Together, these limitations on one's reasonable expectation of privacy in the warrantless search context

\begin{abstract}
public street are readily accessible to animals, children, scavengers, snoops and other members of the public."). Most recently, the Supreme Court considered whether it should carve out an exception to the "no privacy in public" rule for warrantless constant monitoring of a suspect's vehicle via use of a GPS tracking device attached by the government. See United States v. Jones, 132 S. Ct. 945 (2012). Although the space invaded was the suspect's car versus his home, the Court concluded that the search violated the Fourth Amendment because it involved a trespass-like intrusion of a constitutionallyprotected area. Id. at 950. The Court's decision in Jones likely supports my thesis because the Court's analysis focuses on the spatial location of the search and that location's proximity to a traditionally-private space. Id. at 941 ("Where, as here, the Government obtains information by physically intruding on a constitutionally protected area, such a search has undoubtedly occurred.").
\end{abstract}

${ }^{88} \mathrm{Kyllo}, 533$ U.S. at 42 (citations omitted) (" $[\mathrm{I}] \mathrm{t}$ is ... . well settled that searches and seizures of property in plain view are presumptively reasonable."); Oliver v. United States, 466 U.S. 170, 176 (1984) ("[The] special protection accorded by the Fourth Amendment to the people in their 'persons, houses, papers, and effects' is not extended to the open fields. The distinction between the latter and the house is as old as the common law." (citing Hester v. United States, 265 U.S. 57, 59 (1924)).

${ }^{89}$ See Smith v. Maryland, 442 U.S. 735, 743-44 (1979) ("[A] person has no legitimate expectation of privacy in information he voluntarily turns over to third parties."); see generally Orin S. Kerr, Defending the Third Party Doctrine, 24 BERKELEY TECH. L.J. 1229 (2009) (summarizing and defending doctrine); see also SOLOVE, UNDERSTANDING PRIVACY 139-40 (critiquing third party doctrine).

90 See Rehberg v. Paulk, 598 F.3d 1268, 1281-82 (11th Cir. 2010) ("A person also loses a reasonable expectation of privacy in emails, at least after the email is sent to and received by a third party.") (citations omitted).

${ }^{91}$ See Smith, 442 U.S. at 743-44 (concluding that the use of "pen registers" to collect the numbers dialed by phone did not require a warrant because the person using the phone "voluntarily conveyed numerical information to the telephone company"). 
have led some scholars to equate privacy under the Fourth Amendment with "total secrecy." 92

\section{CALLS FOR A Right TO OBSCURITY EXCEPTION TO THE "No PrivaCY IN PUBlic" RULE}

Synthesizing the "no privacy in public" rule from all of the above summarized sources, Daniel Solove insightfully stated as follows: "[A]ccording to the prevailing view of the law, if you're in public, you're exposing what you're doing to others, and it can't be private."93 This prospect of constant potential for exposure has led Solove and others to critique the "no privacy in public" rule as a "binary understanding of privacy" that is both antiquated and inadequate. 94 The rule purportedly is antiquated because of recent technological developments regarding the collection, distribution, and indexing of information that threaten obscurity in ways not anticipated when the rule first emerged. ${ }^{95}$ Next, the rule is inadequate, practically speaking,

92 See Daniel J. Solove, Conceptualizing Privacy, 90 CALIF. L. REV. 1087, 1107 (2002) ("In a variety of legal contexts ... [p]rivacy is thus viewed as coextensive with the total secrecy of information."); William J. Stuntz, Privacy's Problem and the Law of Criminal Procedure, 93 MICH. L. REV. 1016, 1021-22 (1995) (reviewing search and seizure cases and concluding that "the [key] question ... is whether what the police did was likely to capture something secret" and suggesting that "privacy-as-secrecy dominates the case law"); see also Julie E. Cohen, Surveillance: Privacy, Visibility, Transparency, and Exposure, $75 \mathrm{U}$. CHI. L. REV. 181, 190 (2008) (documenting how "the U.S. legal system purports to recognize an interest in spatial privacy").

93 See Solove, FUtURE OF REPUTATION, supra note 18, at 163; SOlOVE, UndERSTANDING PRIVACY, supra note 17 , at 110 .

94 See SOlOVE, FutURE OF RePUTATION, supra note 18, at 7 ("Under existing notions, privacy is often thought of in a binary way-something is either private or public. According to the general rule, if something occurs in a public place, it is not private."); Danielle Keats Citron, Fulfilling Government 2.o's Promise with Robust Privacy Protections, 78 GEO. WASH. L. REV. 822, 827 (2010) ("A public/private binary also may not accord with our lived experiences-individuals routinely carve out zones of privacy in socalled public spaces."); Lipton, supra note 17, at 929-41 (chronicling alleged gaps in current law that fail to protect one's public conduct from capture by handheld cameras and later distribution); SOLOVE, FUTURE OF REPUTATION, supra note 18, at 163 (concluding that the secrecy versus privacy paradigm in the law "has limited the recognition of privacy violations"); SOLOVE, UNDERSTANDING PRIVACY, supra note 17, at 111.

95 See, e.g., Cohen, supra note 92, at 191-92 (critiquing emphasis on public visibility when defining privacy invasions given current surveillance infrastructures); Kevin Werback, Sensors and Sensibilities, 28 CARDOZO L. REV. 2321 (2007) (chronicling perceived threat to privacy in public caused by rising ubiquity and usage of camera phones and other "pervasive sensors"); Erwin Chemerinsky, Rediscovering Brandeis's Right to Privacy, 45 
because it bars people from preventing or recovering for perceived obscurity harms caused by more tech-savvy exposure. ${ }^{96}$ These arguments are summarized in Part III.A, "Technology's Alleged Threat to Obscurity."

Given technology's threat to obscurity, scholars have suggested that a new, more nuanced rule is necessary-one that would recognize claims of privacy in public. ${ }^{97}$ In crafting the proper rule, Daniel Solove suggests that lawmakers conduct a pragmatic balancing of harms and benefits that is better equipped to consider technological developments and their associated privacy harms..$^{8}$ Others implicitly have endorsed this approach. ${ }^{99}$ Part III.B more carefully describes this suggested balancing test replacement. Part III then critiques these Part II arguments as an unnecessary call to protect the mythical right to obscurity. ${ }^{100}$

\begin{abstract}
BRANDEIS L.J. 643, 656 (2007) (calling for the Supreme Court to recognize a privacy interest in the reporting of truthful information because " $t \mathrm{t}]$ echnology that Warren and Brandeis never could have imagined ... presents unprecedented risks to informational privacy"); Abril, supra note 45, at 5 ("New technologies have enabled novel social situations that generate privacy harms and concerns that were unforeseeable."); see generally Andrew Lavoie, Note, The Online Zoom Lens: Why Internet Street-Level Mapping Technologies Demand Reconsideration of the Modern-Day Tort Notion of 'Public Privacy', 43 GA. L. REV. 575 (2009).
\end{abstract}

${ }^{66}$ See e.g., SOLOVE, FUTURE OF REPUTATION supra note 18, at 166 ("[M]erely assessing whether information is exposed in public or to others can no longer be adequate to determining whether we should protect it as private"); Amy Gajda, Judging Journalism:

The Turn Toward Privacy and Judicial Regulation of the Press, 97 CALIF. L. REv. 1039, 1041 (2009) (demonstrating how "growing anxiety about the loss of personal privacy in contemporary society has given new weight to claims of injury from unwanted public exposure") (citing ANITA ALLEN, PRIVACY LAW AND SOCIETY 6 (2007)); Cohen, supra note 92, at 191 (concluding that "prevailing legal understandings of spatial privacy" are inadequate because they do not recognize the spatially harmful alteration of "the spaces and places of everyday life").

${ }_{97}$ SOLOVE, FUTURE OF REPUTATION, supra note 18, at 7, 161 (suggesting a need for "a more nuanced view of privacy"); Chemerinsky, supra note 95, at 656 (suggesting that it is "time to rediscover Warren and Brandeis's right to privacy" because of "unprecedented risks to informational privacy"); Abril, supra note 45, at 4-6 (criticizing courts' "reliance on physical space" as one of the "linchpins" in privacy because "physical space ... no longer is relevant in analyzing many modern online privacy harms"); Lipton, supra note 17.

${ }^{98}$ See infra notes $118-30$ and accompanying text.

99 See, e.g., Lipton, supra note 17, at 943 (summarizing Solove's harm balancing approach and concluding that it "may be the right approach-at least for the present time").

${ }^{100}$ See infra notes 172-269 and accompanying text. 


\section{A. TECHNOLOgY's AllegED THREAT TO OBSCURITY}

In The Future of Reputation, Daniel Solove declares that "modern technology poses a severe challenge to the traditional binary understanding of privacy."101 For Solove and like-minded commentators, the "no privacy in public" rule simply is inadequate in today's tech-savvy information marketplace. ${ }^{102}$ Most concerning, is the three-sided sinister combination of collection, distribution, and indexing technologies. ${ }^{103}$ In the Obscurity Problem scenario, we supposedly are wielding these technologies against ourselves and our fellow citizens. ${ }^{104}$ If we do not do something about the Obscurity

10: SOLOVE, FUTURE OF REPUTATION, supra note 18, at 163.

102 Id. at 166 (opining that because of technological advances, "merely assessing whether information is exposed in public or to others can no longer be adequate to determining whether we should protect it as private"); Lipton, supra note 17, at 930-33 (arguing that current tort laws are inadequate to protect personal privacy interest in conduct shared in public given new technologies such as Facebook, MySpace, YouTube and Flickr); Julie E. Cohen, Examined Lives: Informational Privacy and the Subject as Object, 52 STAN. L. REV. 1373, 1379 (2000) (arguing that private means both "not public" and "not commonowned"); Werback, supra note 95, at 2324-29 (noting threats from various new camera types); see also SOLOVE, UNDERSTANDING PRIVACY, supra note 17, at 4-5 (collecting late 2oth century scholars' statements regarding technology's alleged threat to privacy).

${ }_{103}$ SOlOVE, FUTURE OF REPUTATION, supra note 18 , at 17 ("Often, technology is involved in various privacy problems because it facilitates the gathering, processing and dissemination of information."); Paul M. Schwartz, Privacy and Democracy in Cyberspace, 52 VAND. L. REV. 1607, 1621-41 (1999) (describing supposed "privacy horror show" in cyberspace that "result[s] from the generation, storage and transmission of personal data"); Jacqueline D. Lipton, Digital Multi-Media and the Limits of Privacy Law, 42 CASE W. RES. J. INT'L L. $551,552(2010)$ (stating that "the ability of new digital devices such as cell phone cameras to transmit information wirelessly and globally raises important new challenges for privacy laws"); Cohen, supra note 102, at 1374 (suggesting new informational privacy concerns given "rise of a networked society" that facilitates the rapid search, distribution and connection of one's personal information).

104 SOLOVE, FUTURE OF REPUTATION, supra note 18, at 164 (describing how "[a]rmed with cell phone cameras, everyday people can snap up images, becoming amateur paparazzi"); Lipton, supra note 17 (collecting privacy concerns associated with private citizens' reporting of public conduct by fellow citizens); Marcy Peek, The Observer and the Observed: Re-imagining Privacy Dichotomies in Information Privacy Law, 8 Nw. J. TECH \& INTELL. PROP. 51, (2009) (describing how the fact that "we are all watching each other" alters the privacy analysis). While Solove and Lipton use the term "paparazzi" to describe citizens who use technology to collect and report on their fellow citizens, I prefer the less pejorative term, "citizen journalists." See supra notes 41-42 and accompanying text. As discussed in Part III, I suggest that before we vilify ourselves further, we need to more thoroughly consider the benefits of paparazzi- or citizen-led exposure in the aggregate. See infra notes $215^{-67}$ and accompanying text. 
Problem, "[w]e're heading toward a world where an extensive trail of information fragments about us will be forever preserved on the Internet, displayed instantly in a Google search."105 In this doomsday scenario, "[w]e will be forced to live with a detailed record beginning with childhood that will stay with us for life wherever we go, searchable and accessible from anywhere in the world." 106 In other words, the concern is for the person's sudden and perhaps permanent loss of obscurity.

Victims of the antiquated "no privacy in public" rule are those that shared information or conduct in public with a small group of individuals, only to have that information exposed and exploited by technology. 107 People who have had their obscurity taken away from them via mass Internet-distribution of things they did or said in public include:

- Dog Poop Girl, who refused to clean up her pet dog's excrement on a subway train in South Korea; 108

- Numa Numa Guy, who lip-synched and waved his arms in front of his webcam to the tune of a Moldovan pop song; ${ }^{109}$

105 SOLOVE, FUTURE OF REPUTATION, supra note 18 , at 17 ; see also Peek, supra note 104, at 56-57 (describing how "the aggregation of 'observing' technology enables the private and public sector to create a near perfect picture of the full spectrum of a person's day and a person's life").

${ }^{106}$ SOLOVE, FUTURE OF REPUTATION, supra note 18, at 7 (differentiating online exposures because they involve "taking an event that occurred in one context and significantly altering its nature-by making it permanent and widespread"); DANIEL J. SOLOVE, THE DIGITAL PERSON 1-7 (2004) (discussing threat of "digital dossiers"); Lipton, supra note 17, at 927 (suggesting that new privacy concerns are triggered now that the Internet "makes the dissemination of video ... practically instantaneous and potentially global in scope").

107 SOLOVE, UNDERSTANDING PRIVACY, supra note 17, at 96 (suggesting that "[d]isclosing people's secrets . . . often affects a few unfortunate individuals" whose "lives are ruined for very little corresponding change in social norms").

${ }^{108}$ SOLOVE, FUTURE OF REPUTATION, supra note 18, at 1-4; Lipton, supra note 17, at 921.

109 SOlOVE, FUTURE OF REPUTATION, supra note 18, at 42. Numa Numa Guy, also known as Gary Brolsma, later went on to make more videos, which he posted online; one featured "Star Wars Kid" in a cameo appearance. 
- Star Wars Kid, who performed a series of "Jedi" physical maneuvers, wielding a golf-ball retrieving stick as lightsaber-like weapon; ${ }^{110}$

- Laura K., a college student who propositioned and paid a part-time blogger/actor to write a paper for her regarding Hinduism; ${ }^{111}$

- Jonas Blank, a law firm summer associate whose profanity-laced email came across as a mockery of his employers and work; ${ }^{112}$

- Robert, whose sexual exploits and difficulties were blogged about by his partner, Jessica Cutler, also known as "Washingtonienne;"113

- Geoffrey Peck, whose attempt to cut his wrists was captured by a surveillance camera; ${ }^{114}$

\begin{abstract}
${ }^{110}$ Id. at 44-8. The original less-than-two-minute video of Star Wars Kid was posted to the Internet by a high-school acquaintance of its star without the Kid's express consent. Thus, there is some question regarding whether his performance was done "in public," and, as a result, falls outside the scope of the "no privacy in public" rule. Someone else later edited the video to include Star Wars music and visual effects, which increased the original video's popularity.
\end{abstract}

11Id. at 76-78; Scott Jaschik, Busted for a Bogus Paper, INSIDE HIGHER ED (Mar. 31, 2005, 4:00 AM), http://www.insidehighered.com/news/2005/03/31/plagiarize.

${ }^{112}$ See SOlOVE, FUTURE OF REPUTATION, supra note 18, at 29-30 (citing Ben McGrath, OOps, THE NEW YORKER, June 30, 2003).

113 SOLOVE, FUTURE OF REPUTATION, supra note 18, at 134-35; West, Story of Us, infra note 257 , at $597-600$.

${ }_{114}$ See SOLOVE, UNDERSTANDING PRIVACY, supra note 17, at 195. Initially, an English court found no privacy violation in this case "because the plaintiff's 'actions were already in the public domain,' and revealing the footage 'simply distributed a public event to a wider public." SOLOVE, UNDERSTANDING PRIVACY, supra note 17, at 195. However, the European Court of Human Rights instead disagreed, concluding that there was a privacy violation because the person was not a public figure, while emphasizing "the [systemic] recording of the data" and the "permanent nature of the record." Peck v. United

Kingdom, HUDOC (April 4, 2003), available at http://cmiskp.echr.coe.int/tkp197/view.asp?item=2\&portal=hbkm\&action=html\&highligh $\mathrm{t}=$ peck\&sessionid $=88009156 \&$ skin $=$ hudoc-en. 
- Todd, whose allegedly bad dating behavior was shared on the "don't date him girl" website;115

- Michael, who wrote about his time in juvenile detention without considering that such information would be available to later acquaintances via a Google search of his name. ${ }^{116}$

The emerging consensus appears to be that the above-listed people were victimized via exposure that went beyond what they expected at the time that they shared the information with at least one other person. ${ }^{17}$ Concern over this widespread exposure has led some scholars to call for legal protections for "information that has been shared to a few others, but is still not generally known." 118 The concern is not about the person's privacy, necessarily, because the information was shared with others, sometimes in a public place. Rather, the concern is for the exposed person's loss of obscurity. ${ }^{119}$ Ultimately, the

115 See SOLOVE, FUTURE OF REPUTATION, supra note 18, at 121.

${ }^{116}$ See Solove, supra note $\mathbf{1}$, at 1055 .

${ }_{17}$ See SOLOVE, FUTURE OF REPUTATION, supra note 18 , at 170 ("Privacy can be violated not just by revealing previously concealed secrets, but by increasing the accessibility to information already available."); Chemerinsky, supra note 95, at 656 (suggesting additional privacy protections are needed given the that "the Internet makes [personal information] potentially available to many"); Lipton, supra note 17, at 927 (arguing that current exposures are more harmful because the coupling of cameras and the Internet "makes the dissemination of video ... practically instantaneous and potentially global in scope").

${ }_{118}$ Richards, supra note 61, at 51 (criticizing Warren and Brandeis's division between public and private as "the dominant question in privacy law"); see also Cohen, supra note 102 , at 1379 (suggesting that some information may no longer be a secret but still worthy of privacy protection because it is not commonly known).

${ }^{119}$ See SOLOVE, FUTURE OF REPUTATION, supra note 18 , at 7 ("People who act inappropriately might not be able to escape into obscurity anymore; instead, they may be captured in pixels and plastered across the Internet."); Citron, supra note 94, at 835 (endorsing social-media researcher's concern that people "live by security through obscurity"). 
"no privacy in public" rule is labeled obsolete because it does not protect a person's perceived right to obscurity. ${ }^{120}$

\section{B. Suggested Pragmatic Balancing to Protect Obscurity}

To protect obscurity, some suggest that "[t]he law should begin to recognize some degree of privacy in public."121 Defining exactly when the law should do so has proven difficult; ${ }^{122}$ however, one recentlycrafted approach appears promising. In his latest book, Understanding Privacy, Daniel Solove constructs a "new understanding" of privacy, in which he urges us to "understand privacy as a set of protections against a plurality of distinct but related problems." 123 The problem-based approach is an offshoot of the more general theory of pragmatism, which other scholars explicitly and implicitly endorse. ${ }^{124}$

${ }_{120}$ Wide circulation of information also was part of what motivated Warren and Brandeis's call for a right to privacy. See Warren \& Brandeis, supra note 36, at 196 ("Even gossip apparently harmless, when widely and persistently circulated, is potent for evil.").

${ }^{121}$ See SOLOVE, FUTURE OF REPUTATION, supra note 18 , at 168; Lipton, supra note 17 , at 930-33 (suggesting that current tort laws are insufficient to protect privacy from picturetaking and other technological advances); Cohen, supra note 92, at 181 (arguing that person's privacy interest "is not negated by the fact that people in public spaces expect to be visible to others present in those spaces").

122 See Solove, THE FUTURE OF RePUTATION, supra note 18, at 168 (describing "The Difficulties of Recognizing Privacy in Public"); Warren \& Brandeis, supra note 36, at 214 ("To determine in advance of experience the exact line at which the dignity and convenience of the individual must yield to the demands of the public welfare or of private justice would be a difficult task ....").

123 Solove, Understanding PRIVACy, supra note 17, at 171.

${ }^{124}$ See, e.g., Strahilevitz, Reunifying, supra note 35, at 2032 (including whether "the gravity of the harm to the plaintiff s privacy interest [is] outweighed by a paramount public policy interest" as a third element in his proposed privacy tort); SOLOVE, UNDERSTANDING PRIVACY, supra note 17, at 46-47 (acknowledging pro-pragmatism scholars such as William James, John Dewey, George Herbert Mead, Richard Rorty, Richard Posner, and Cornell West). Although legal scholars generally do not agree as to the proper definition of, or application of, pragmatism and the law, see Michael Sullivan \& Daniel Solove, Can Pragmatism Be Radical? Richard Posner and Legal Pragmatism, 113 YALE L.J. 687 (2003) (critiquing Richard Posner's use of pragmatism), for the purposes of this article, pragmatism essentially means analyzing privacy "in specific contextual situations" versus universal absolutisms. SOLOVE, UNDERSTANDING PRIVACY, supra note 17, at 47. 
Under Solove's proposed approach, the first step is to identify whether a potential privacy problem exists.125 After identifying the problem, the next step is to analyze the different types of harms created by the privacy problem." 126 When tabulating the harms, we are to consider them in the aggregate versus with respect to only a single person, i.e., we are to calculate the "value of privacy . . . in terms of its contribution to society" as well as to the individual exposed. ${ }^{127}$ After identifying the privacy problem and valuing the harm caused, we are to "assess . . . the value of any conflicting interests." 128 Finally, we perform a balancing to "determine which prevails." 129 If the harms to privacy are greater than the value ${ }^{130}$ of the conflicting interests, the law should protect them at the expense of those interests. ${ }^{13}{ }^{1}$ On the other hand, if the conflicting interests are greater, then they should win at the expense of privacy, and no reform is necessary. ${ }^{132}$ The latter is the position of this Article, with respect to citizen journalists'

\footnotetext{
125 SOLOVE, UNDERSTANDING PRIVACY, supra note 17 , at 189 (suggesting that a problem arises when, aided by technology, people, businesses, and governments engage in "activities that disrupt other activities that we value and thus create a problem").
}

${ }_{126}$ SOLOVE, UNDERSTANDING PRIVACY, supra note 17, at 174-79 (noting that categories of harm include physical injuries, financial losses, and property harms, reputational harms, emotional and psychological harms, relationship harms, vulnerability harms, chilling effects, and power imbalances).

${ }^{127 I d}$. at 173-74 ("[W] hen privacy protects the individual, it does so because it is in society's best interest. Individual liberties should be justified in terms of their social contribution.").

${ }^{128}$ Id. at 183.

$129 I d$.

${ }_{130} \mathrm{Id}$. at 10 ("The value of privacy in a particular context depends upon the social importance of the activities that it facilitates.").

${ }^{131}$ SOlOVE, UNDERSTANDING PRIVACY, supra note 17, at 183; id. at 185 (acknowledging that value assigned to harms will vary across cultures, even among supposedly similar groupsAmericans and Europeans.); id. at 179 (noting that in those cases, public policy then should "effectively redress the harms caused by the problems" via "individual enforcement mechanisms"); id. at 181 (further suggesting that the law should permit recovery of "true liquidated damages without requiring proof of any specific individual harm").

${ }^{132}$ See, e.g. SOlOVE, Understanding PRIVACY, supra note 17, at 48 ("Few would contend that when a crime victim tells the police about the perpetrator, it violates the criminal's privacy."). See also SOLOVE, UNDERSTANDING PRIVACY, supra note 17, at 189 ("The way to address privacy problems is to reconcile conflicts between activities."). 
exposure of statements or actions shared in public, i.e., the Obscurity Problem. ${ }^{133}$

\section{HOW THE BENEFITS OF EXPOSURE OUTWEIGH OBSCURITY HARMS}

This Part applies the above-described pragmatic balancing test to the Obscurity Problem. ${ }^{134}$ The Obscurity Problem category encompasses situations such as Dog Poop Girl and Robert, listed in Part II.A, and Officer Walsh, as shared in the Introduction. ${ }^{135}$ Presently, many scholars contend that affording some "privacy in public" to these and similar individuals is desirable in order to eliminate, or at least minimize the Obscurity Problem. ${ }^{136}$ Essentially, they appear to argue that sometimes society's interest in keeping truthful information within an individual's own sole control is greater than the public's interest in knowing, possessing and using that same truthful information, even if the information initially was shared in public.

To test these scholars' hypothesis regarding the Obscurity Problem, the pragmatic balancing approach described in Part II.B requires us to catalog the societal harms triggered by the Obscurity Problem and then compare those harms to the positive benefits of the associated exposure.137 Toward this end, Part III.A documents the alleged privacy-related harms of the Obscurity Problem, and shows

133 See SOLOVE, UNDERSTANDING PrIVACY, supra note 17, at 121-26; see also supra notes 41-42 and accompanying text (defining the "Obscurity Problem").

${ }_{134}$ See SOlOVE, UNDERSTANDING PRIVACY, supra note 17, at 121-26; see also supra notes 41-42 and accompanying text (defining the "Obscurity Problem").

135 See supra notes 2-8 and accompanying text; see also, SOLOVE, FUTURE OF REPUTATION, supra note 18, at 106-10; see also Peek, supra note 104, at 56-57; see SOLOVE, FUTURE OF REPUTATION, supra note 18 , at $44-48$.

${ }^{136}$ See, e.g., Solove, supra note 92, at 1109-16 (collecting scholarship regarding privacy as "control over personal information" and acknowledging that some information falls outside the scope of "what society deems appropriate to protect"); Lipton, supra note 17, at 93033; Cohen, supra note 92, at 181 .

137 SOLOVE, UNDERSTANDING PRIVACY, supra note 17, at 187 ("Protecting privacy requires careful balancing because neither privacy nor its countervailing interests are absolute values."); SOLOVE, UNDERSTANDING PRIVACY, supra note 17, at 84 ("As I have sought to define it, privacy involves protection against a plurality of kinds of problems. Articulating the value of privacy consists of describing the benefits of protecting against these problems."). 
how they may have been overstated. ${ }^{138}$ Part III.B then documents the benefits of exposure in this type of situation, and shows how they have likely been overlooked or undervalued. ${ }^{139}$ In Part III.C, I suggest that overstating the harms and understating the benefits of the Obscurity Problem has resulted in an unnecessary call for changing the "no privacy in public" rule in all cases other than those special cases discussed in Part III.D. ${ }^{140}$ I later conclude that, in the clash between citizen exposure of public conduct versus obscurity, exposure should win. ${ }^{141}$

\section{A. HARMS FROM THE OBSCURITY PROBLEM}

Each privacy problem involves a combination of harms. ${ }^{142}$ The Obscurity Problem reportedly triggers two key harms. First, the Obscurity Problem harms the exposed person's emotional and psychological well-being. ${ }^{143}$ I call this the "dignity" harm. ${ }^{144}$ For example, when Dog Poop Girl found out that her picture and criticism of her conduct were posted all over the Internet, she felt undignified and attacked. ${ }^{145}$ Robert, whose sexual preferences and proclivities were shared in a blog post, experienced similar kinds of emotional

${ }^{138}$ See infra notes $139-215$ and accompanying text.

${ }^{139}$ See infra notes 216-67 and accompanying text. As noted below, one scholar who has begun demonstrating the many societal benefits of more truthful information being available about everyone is Lior Jacob Strahilevitz. See generally Strahilevitz, Reputation Nation, supra note 33; but see Strahilevitz, Reputation Nation, supra note 33, at 1677 ("More information is not always better. Nor is it always worse.").

140 See infra notes $268-78$ and accompanying text.

${ }^{141}$ See infra notes $279-83$ and accompanying text.

${ }_{142}$ See SOlOVE, UNDERSTANDING PRIVACY, supra note 17, at 173 (showing that privacy's value "varies across different contexts depending upon which form of privacy is involved and what range of activities are imperiled by a particular problem").

${ }^{143}$ See Id. at $175-76$.

${ }^{144}$ Solove also discusses the reputational harm; however, defamation law generally recognizes a reputational harm only from false or misleading information. The Obscurity Problem, in contrast, only involves exposure of truthful statements or actions.

145 The harm to dignity also may lead to secondary harms of changed choices and paths in life, such as when Dog Poop Girl quit her job. Lipton, supra note 17, at 921 (citing JONATHAN ZITTRAIN, THE FUTURE OF THE INTERNET-AND HOW TO STOP IT 211 (2008)). 
harm. ${ }^{146}$ Second, an Obscurity Problem, or even just the threat of one, allegedly harms one's relationship security, ${ }^{147}$ which in turn leads to speech-related chilling effects. ${ }^{148}$ I call this the "thinking space" harm. For example, knowing that one's thoughts may be recorded and later exposed to the world-like what happened to now-Justice Sotomayor's "wise Latina" speech-may discourage people from speaking their minds and prevent the promotion of good ideas. ${ }^{149}$ In sum, the Obscurity Problem is perceived as harmful because it harms one's personal emotions and chills one's intellectual discourse, both of which threaten society as a whole. ${ }^{150}$ Each of these two categories of harm is discussed below in more detail.

\section{HARM TO DIGNITY}

As detailed above, scholars have argued that two particular aspects of the Obscurity Problem tend to cause harm to one's psyche-the sharing of information with many more people than originally anticipated and the ease of access to that information over a long period of time.151 The target of the exposure is subjected to "unwanted

${ }^{146}$ See supra note 110 and accompanying text.
${ }^{147}$ SOLOVE, UNDERSTANDING PRIVACY, supra note 17 , at $176-77$.

${ }^{148} \mathrm{Id}$. at 178 . There "may be a widespread chilling effect when people are generally aware of the possibility of surveillance but are never sure if they are watched at any particular moment." Id. at 109.

149 See Charlie Savage, A Judge's View of Judging Is on the Record, N.Y. TimEs, May 15, 2009, at A21 (describing video recording of speech by then-Judge Sotomayor in which she stated her "hope that a wise Latina woman with the richness of her experiences would more often than not reach a better conclusion than a white male who hasn't lived that life" and documenting the associated uproar upon release of the video following her nomination to the Supreme Court).

${ }^{150}$ Interestingly, these harms appear to dovetail with the harms that most concerned Warren and Brandeis, i.e., specific harm to the "feelings and personalities of individuals" and general harms to "the level of public discourse in the press" and a "lowering of social standards and morality." Warren \& Brandeis, supra note 36 at 196; see also Richards, supra note 61 , at $1302-03$.

${ }^{151}$ SOlOVE, UNDERSTANDING PRIVACY', supra note 17, at 145-46 ("The harm of disclosure is not so much the elimination of secrecy as it is the spreading of information beyond expected boundaries. People often disclose information to a limited circle of friends, and they expect the information to stay within this group."); Cohen, supra note 102, at 1379 (suggesting difference between publicly known and commonly known information); Chemerinsky, supra note 95, at 656 (arguing that Internet exposure is different due to larger audience); Lipton, supra note 17, at 927 (arguing that current exposures are more 
notoriety" $15^{2}$ which "can result in embarrassment, humiliation, stigma and reputational harm."153 These feelings generally could be characterized as a loss of dignity. 154

The mere possibility of subsequent over-distribution also purportedly affects one's emotions, causing "feelings of anxiety and discomfort." 155 Similarly, the possibility of information collection, even if not actually conducted, leads to a perceived loss of solitude.156 The fear that a person's personal zone of public space may be intruded upon, "makes her feel uncomfortable and uneasy." 157 Perhaps some of these anxious feelings are due to the purportedly permanent nature of the information on the Internet.158 This potential for reputation-

harmful because of publication that is "global in scope"). Sometimes this "increased accessibility" is described as a harm in and of itself. SOLOVE, UNDERSTANDING PRIVACY, supra note 17, at 151 (describing the "harm of increased accessibility").

${ }_{152}$ See Solove, Understanding PrVAacy, supra note 17, at 157 (quoting Roberson v. Rochester Folding Box Co., 64 N.E. 442, 449 (N.Y. 1902) (Gray, J., dissenting)).

153 Id. at 160; see id. at 147 (opining that exposure "often creates embarrassment and humiliation" especially if it involves "information about our bodies and health" or information society deems "animal-like or disgusting").

154 See id. at 148 ("We protect against the exposure of these bodily aspects because this protection safeguards human dignity as defined by modern society. Dignity is a part of being civilized; it involves the ability to transcend one's animal nature.") (citation omitted); see also Warren \& Brandeis, supra note 36, at 196 (suggesting that "modern enterprise and invention have, through invasions upon his privacy, subjected [man] to mental pain and distress, far greater than could be inflicted by mere bodily injury").

155 SOLOVE, UNDERSTANDING PRIVACY, supra note 17, at 107-08 ("[P] eople expect to be looked at when they ride the bus or subway, but persistent gawking can create feelings of anxiety and discomfort.").

${ }^{156} \mathrm{Id}$. at 163 (" $[\mathrm{I}]$ ntrusion can cause harm even if no information is involved [because] intrusion often interferes with solitude-the state of being alone or able to retreat from the presence of others.").

${ }^{157}$ Id. at 162; see Warren \& Brandeis, supra note 36 , at 195 (defining right "to be let alone") (citation omitted); Olmstead v. U.S., 277 U.S. 438, 478 (1928) (Brandeis, J., dissenting) (suggesting that "right to be let alone" is "the most comprehensive of rights and the right most valued by civilized men").

${ }_{158}^{8}$ The Internet and related technologies reportedly escalate the harm of the exposure because they "transform gossip into a widespread and permanent stain." SOLOVE, FUTURE OF REPUTATION, supra note 18, at 181; see also Solove, supra note 1, at 969 ("Without warning, anyone can broadcast another's unguarded moments ... of youthful awkwardness to an audience of millions" and, via Internet archives, "ensure that embarrassing material follows a victim for life."). 
staining reportedly "makes a person [feel like] a 'prisoner of his recorded past,"'159 and sacrifices the exposed person's opportunity at a second chance. ${ }^{160}$ Ultimately, these threats may cause one to feel like she has lost control over her entire self ${ }^{161}$ and give others an inaccurate $^{162}$ picture of her.

\section{HARM TO THINKING SPACE}

The second category of harm the Obscurity Problem allegedly causes, involves more than realized or feared internal feelings of lost dignity; rather, it involves changed behavior of individuals, which, in turn, causes harm to society as a whole. In particular, the failure to protect people from the Obscurity Problem reportedly threatens to harm their expressive activities and the personal relationships that foster such activities. ${ }^{163}$ Depriving someone of "breathing space" in

159 SOLOVE, UNDERSTANDING PRIVACX, supra note 17, at 145 (citation omitted).

${ }^{160}$ Solove, supra note 1, at 1053. "One of the values of protecting privacy is facilitating growth and reformation." Id. at 1054 (acknowledging that "[e]veryone has done things and regretted them later" and suggesting that "[ $t]$ here is a great value in allowing individuals the opportunity to wipe the slate clean" in order to "further society's interest in providing people with incentives and room to change and grow").

${ }^{16:}$ SOLOVE, UNDERSTANDING PRIVACY, supra note 17 , at 153 (concluding that "the more people know about us, the more they can exercise control over us"). SOLOVE, UNDERSTANDING PRIVACY, supra note 17, at 154 (warning that "[t] hreatening to disseminate information can achieve levels of domination that may not be socially beneficial").

${ }^{162}$ Many claim that this kind of exposure is inaccurate because it is incomplete. Solove, supra note 1, at 1035-36 (endorsing Jeffrey Rosen's observation that “[p]rivacy protects us from being misdefined and judged out of context in a world of short attention spans, a world in which information can easily be confused with knowledge"); Lipton, supra note 17, at 927-29 (discussing harmful misinterpretation that occurs when one's image is taken out of context); JEFFREY ROSEN, THE UNWANTED GAZE 9 (2000) ("[W] hen intimate information is removed from its original context and revealed to strangers, we are vulnerable to being misjudged on the basis of our most embarrassing ... tastes and preferences.").

163 Solove, Understanding PrIVACY, supra note 17, at 78 ("Privacy problems impede certain activities, and the value of privacy emerges from the value of preserving these activities."); ROSEN, supra note 162, at 8 ("In order to flourish, the intimate relationships on which true knowledge of another person depends need space as well as time: sanctuaries from the gaze of the crowd in which slow mutual self-disclosure is possible.") (citing SOlOVE, UNDERSTANDING PRIVACY, supra note 17, at 79-80). 
public, it is argued, also deprives him of his "freedom of thought,"164 whether alone or with others, ${ }^{165}$ which also triggers First Amendment freedom of association concerns. ${ }^{166}$

With respect to the need for individual "thinking space," scholars have stated that obscurity "preserve[s] space for new ideas to develop." 167 Without some privacy in public, people will lose the "moments for intellectual and spiritual contemplation" that privacy in public provides. ${ }^{168}$ This type of harm occurs regardless of whether the exposure actually happens or not. ${ }^{169}$ The actual or threatened loss of obscurity chills not only political but also creative expression because people wish to avoid having their ideas "prematurely leaked to the world, where harsh judgments might crush them."170 A sense of private space in public also reportedly is crucial to intellectual relationships with others, especially political ones. Specifically, "public surveillance can have chilling effects that make people less likely to

${ }_{164}$ Richards, supra note 61, at 1324-25; SOlOve, Understanding PrIVACY, supra note 17, at 169 .

${ }^{165}$ This argument appears supported by an emerging scholarly effort to draw a line around, and better protect, "intellectual privacy." See generally Neil M. Richards, Intellectual Privacy, 87 TEX. L. REV. 387 (2008). To define when intellectual privacy interests are at stake, one asks "whether the information being sought is relevant to the activities of thinking, reading and discussion safeguarded by the First Amendment." If the answer is "yes," then a higher level of protection should result. Richards, supra note 61, at 1349.

${ }_{166}$ See, e.g., Katherine J. Strandburg, Freedom of Association in a Networked World: First Amendment Regulation of Relational Surveillance, 49 B.C. L. REV. 741 (2008).

${ }^{167}$ Richards, supra note 61, at 46; Richards, supra note 165 , at 412-16 (arguing that spatial privacy is necessary for thought development).

${ }^{168}$ SOLOVE, UNDERSTANDING PRIVACY, supra note 17, at 79 (citing material from Joseph Bensman and Arnold Simmel); Cohen, supra note 102, at 1377 ("We must carve out protected zones of personal autonomy, so that productive expression and development can have room to flourish.")

169 SOLOVE, UNDERSTANDING PRIVACY, supra note 17, at 143 (opining that the mere "risk of disclosure can prevent people from engaging in activities that further their own selfdevelopment" and "inhibit people from associating with others"); Solove, Conceptualizing Privacy, supra note 92, at 1121 (quoting Gerstein for principle that "intimate relationships simply could not exist if we did not (have] privacy for them"); Richards, supra note 165, at 403 ("In a world of widespread public and private scrutiny, novel but unpopular ideas would have little room to breathe ... and original ideas would have no refuge in which to develop.").

170 SOLOVE, UNDERSTANDING PRIVACY, supra note 17, at 80. 
associate with certain groups, attend rallies, or speak at meetings." ${ }^{171}$ Privacy and obscurity allegedly "underwrite[] the freedom to vote, to hold political discussions, and to associate freely away from the glare of the public and without fear of reprisal." ${ }^{172}$ Further, whether individually or in groups, protection against disclosure "also facilitates the reading and consumption of ideas." 173 This is because disclosure, coupled with the perceived permanency of the Internet "attaches informational baggage to people" so that a thought exposed once will be associated with that person permanently. ${ }^{174}$ Ultimately, as "a tool of social control," the Obscurity Problem purportedly "cause[s] [a] person to alter her behavior [through] self-censorship and inhibition," thus reducing the number of helpful activities for society. ${ }^{175}$

\section{How the Obscurity Problem Harms are OVERSTATED VIA ASSUMPTIONS}

Simply, and perhaps harshly stated, the primary alleged harms of an Obscurity Problem are that: (i) it makes the exposed person feel bad about himself, sometimes for a very long time, and (ii) it makes some people think twice before they share their thoughts or actions with others in public. Both harms are based on certain questionable assumptions, each of which is challenged below.

${ }^{171}$ Id. at 112.

172 Solove, supra note 1, at 993 (quoting OWEN M. FISS, THE IRONY OF FREE SPEECH 3 (1996)); Solove, supra note 1, at 993-94 (concluding that "without privacy, people might not communicate many ideas" and that threat of disclosure "probably will not end all conversations, but it will alter what is said"); Richards, supra note 61, at 1341-42 (suggesting that in order to "govern themselves," citizens need "space [free] from state scrutiny of their "beliefs, thoughts, and emotions'").

173 See Solove, supra note 1, at 992 (citing Julie E. Cohen, A Right to Read Anonymously: A Closer Look at "Copyright Management" in Cyberspace, 28 ConN. L. REV. 981, 1012-13 (1996)).

174 Solove, Understanding PrIVACY, supra note 17, at 124.

175 Id. at 108. 


\section{a. Refuting Assumptions that the Dignity Harm is Permanent, Irrefutable, and Quantifiable}

The first harm most often associated with the Obscurity Problem is a loss of dignity or other emotional harm felt by the person exposed and by persons who fear such exposure. ${ }^{176} \mathrm{I}$ do not question that some people subjected to the Obscurity Problem suffer some emotional harm that causes them sincere pain. ${ }^{177}$ However, I do question whether this harm, as some scholars appear to have assumed or argued, is permanent, irrefutable, and quantifiable.

The first assumption that potentially exaggerates the dignity harm is the assumption that such harm is permanent. ${ }^{178}$ As noted above, some scholars claim that the Obscurity Problem makes one a "prisoner of his recorded past," suggesting that once one is exposed, one permanently drags around the exposed information like a tattoo or like a ball and chain around one's neck. ${ }^{179}$ However, a cursory "where are they now"-style Internet search for the most oft-cited victims of the Obscurity Problem, ${ }^{180}$ reveals that many were not damaged as much as one initially would think. Others that initially were harmed have returned to or risen to positions objectively better than before the exposure. For example, "Star Wars Kid," now a young adult, serves as President of a conservation society while studying for

\footnotetext{
${ }_{176}$ See supra notes 141-59 and accompanying text (discussing dignity harm and acknowledging that it includes other related harms such as increased anxiety); see M. Ryan Calo, The Boundaries of Privacy Harm, 86 IND. L.J. 1131, 1145 (2011) (documenting examples of dignity harm under the label of "subjective harm").

17 See supra notes 141-59 and accompanying text.

${ }^{178}$ SOLOVE, FUtURE OF REPUTATION, supra note 18 , at 94 ("One of the chief drawbacks of Internet shaming is the permanence of its effects. ... Being shamed in cyberspace is akin to being marked for life."). In part, this argument appears to suggest that we should be more afraid of information when it is more permanent, a suggestion that also could support limiting hardcover books because they are more durable and longer-lasting than paperbacks.
}

179 SOLOVE, UNDERSTANDING PRIVACY, supra note 17, at 145; see SOlOVE, FUTURE OF REPUTATION, supra note 18 , at 94 (suggesting that being exposed for public conduct via the Internet is "similar to being forced to wear a digital scarlet letter or being branded or tattooed").

${ }^{180}$ See supra notes 104-14 and accompanying text. 
his law degree at McGill. ${ }^{181}$ Jonas Blank, the law firm associate whose profanely critical email traveled around the world, was hired full-time by the same top law firm he criticized. ${ }^{182}$ Countless others had their fifteen minutes of undignified fame fade even before or shortly after rising to the pitied status of an "example used in privacy scholar's work." 183 Further, the average shelf-life of any documented dignity harm likely will fade even more rapidly as more people are exposed, i.e., as the democratization of exposure expands. ${ }^{184}$ This is because the increased amount of information available about individuals, and the ever-decreasing window of time during which a single piece of information remains in the public's collective interest, makes any one exposure less and less noticeable.185 In sum, as more information about more people is made available in a shorter and shorter news cycle, the staying power of any one exposure is limited and the supposed permanence of the dignity harm grows ever more questionable. ${ }^{186}$

\footnotetext{
${ }^{181}$ See Alex Pasternack, After Lawsuits and Therapy, Star Wars Kid is Back, MOTHERBOARD (June 1, 2010), http://motherboard.vice.com/2010/6/1/after-lawsuitsand-therapy-star-wars-kid-is-back.
}

${ }_{182}$ The law firm, Skadden, Arps, Slate, Meagher \& Flom LLP, offered Mr. Blank a full-time position with the firm, which he accepted. He now works at a different New York City law firm. See David Lat, Our Favorite Skadden Associate Moves On, ABOVE THE LAW (Mar. 30, 2007, 2:36 PM), http://abovethelaw.com/2007/o3/our-favorite-skadden-associatemoves-on.

${ }_{18}$ See Schwartz, supra note 7, at 1444-45 (discussing how Solove's depictions of exposed individuals perhaps perpetuates the very harm he identifies as troubling).

${ }^{184}$ See Aaron Perzanowski, Comment, Relative Access to Corrective Speech: A New Test for Requiring Actual Malice, 94 CALIF. L. REV. 833, 833-34 (2006) (referencing "the democratization of the means of mass communication spurred by modern technology" as reason to question the public figure doctrine in defamation law).

${ }_{185}$ See Gloria Franke, Note, The Right of Publicity vs. The First Amendment: Will One Test Ever Capture the Starring Role?, 79 S. CAL. L. REV. 945, 989 (noting "democratization of celebrity" and the power of the Internet to "empower[] the formerly voiceless") (citation omitted).

${ }^{186}$ I suspect that some exposed persons, like the public at large, subjectively do not experience the harm others project upon them. See, e.g., Eric Goldman, The Privacy Hoax, FORBES, Oct. 14, 2002, at 42, available at http://www.forbes.com/forbes/2002/1014/042.html (discussing how consumer behavior regarding privacy demonstrates a lack of sincere interest in personal privacy and, on that basis, questioning the need for additional government regulation). 
The dignity harm also may be overstated because it appears based, at least in part, on the assumption that the victim of the harm cannot reduce the harm by responding in her defense. After an exposure, some serious emotional damage may have been done; however, that does not mean that it cannot be mitigated. Every alleged victim of an exposure has the opportunity to post a reply and many are quite effective. ${ }^{187}$ Even Dog Poop Girl posted an online apology. ${ }^{188}$ Additionally, exposure on the Internet unleashes a mob of eager factcheckers, raring to go and expose the initial citizen journalist as a fraud. For example, when Department of Agriculture official Shirley Sherrod was falsely "exposed" for saying, on tape, that she purposefully refused to help a farmer of a different race than her own, but further, near-immediate exposure, through the posting of and commentary regarding the entire tape, revealed that she in fact did help the farmer and that she learned a great lesson regarding race and class in society. ${ }^{189}$ In this respect, exposing the information to a large mass of people simultaneously helped improve the accuracy of the information. This automatic "right to reply" has not always been available (simply put, not everyone owned a newspaper) but now, the very technology some vilify is the same technology that empowers a reply. ${ }^{190}$ And, most importantly, every reply reduces the harm associated with the exposure and loss of obscurity. ${ }^{191}$

187 See Lauren Gelman, Privacy, Free Speech, and "Blurry-Edged" Social Networks, 50 B.C. L. REV. 1315, 1315-16 (2009) ("For the first time in history, the economics of publishing place the individual speaker on even ground with institutional speakers" such that "any person can tell her story to the world.").

${ }^{188}$ See Dog Poo Girl, KNOW Your MEME, http://knowyourmeme.com/memes/dog-poogirl\# (last updated Nov. 7, 2011) (providing screen capture of apology).

${ }^{189}$ See Viveca Novak, Shirley Sherrod's Contextual Nightmare, FACTCHECK.ORG, (July 21, 2010), http://www.factcheck.org/2010/07/shirley-sherrods-contextual-nightmare.

${ }^{190}$ See Perzonowski, supra, note 184 , at 836 (contrasting the difficulty of responding to a newspaper's accusations with the relative ease of responding to an online source's publication of the same accusations and concluding that, with the latter, the "easiest and most effective strategy is simply to correct the misinformation through [one's] own response"). As Perzonowski states, "In the time it would take to contact a lawyer, [someone wrongly exposed online] could compose a response that would counter the misinformation and prevent or repair any harm to her reputation." Id. at 836 .

${ }^{191}$ The reporting of, and replies to, more reputation-related information in turn will likely lead to more complete and more accurate assessments of an individual's actual qualities. See Strahilevitz, supra note 33, at 1670-75 (chronicling developments leading to "reputation revolution"). 
Finally, the dignity harm often is overstated because it cannot be quantified. Emotional harm is inherently subjective. ${ }^{192}$ The only one who accurately can quantify the harm is the person affected, and there is no direct way for the rest of us to get inside her head and feel the harm in the same way she feels it. This difficulty has led, at least in part, to the law's skepticism of emotional harm, especially when the alleged harm was caused by the sharing of truthful information. For example, a privacy tort plaintiff must be able to point to a specific harm, such as a reputational loss, versus mere "hurt feelings," in order to obtain damages. ${ }^{193}$ The Supreme Court, too, has expressed a reluctance to limit speech based on its potential to hurt feelings. ${ }^{194}$ Although it remains possible to assess the harm on an objective basis, assuming a rational, reasonable audience, ${ }^{195}$ the currently unquantifiable nature of emotional harm makes the dignity harm a weak leg on which to support a right to obscurity. ${ }^{196}$ Further, to the extent it can be quantified, the dignity harm likely is offset by the emotional benefits of exposure, as discussed in Part B below.

\section{b. Refuting the Assumptions that Private Thinking Space in Public is Necessary and Unavailable}

The next harm-previously described as the destruction of perceived "thinking space"-is also overstated due to its apparent reliance on a questionable assumption. Namely, this harm assumes that a public, yet somewhat secure space absolutely free from later reporting by anyone of what has transpired there is necessary for, and helpful to thought development and free association, especially

\footnotetext{
192 See Calo, supra note 176, at 1145 (describing various subjective harms).

193 See Richards, supra note 61, at 1345 (“[A] hallmark of modern American First Amendment jurisprudence is that hurt feelings alone cannot justify the suppression of truthful information or opinion.").
}

194 See R.A.V. v. City of St. Paul, Minn., 505 U.S. 377, 414 (1992) (striking down an ordinance that criminalized conduct which caused mere hurt feelings).

${ }^{195}$ See Lyrissa Barnett Lidsky, Nobody's Fools: The Rational Audience as First Amendment Ideal, 2010 U. ILL. L. REV. 799, 802-04 (discussing Supreme Court justices' "constitutional preference for standards based on a rational audience rather than a real one").

196 Richards, supra note 61, at 1346 ("As Brandeis himself implicitly recognized later in life, a tort-based conception of privacy protecting against purely emotional harm must remain exceptional in a constitutional regime dedicated to speech, publicity, and disclosure."). 
political thought and association. More pointedly, some seem to fear that if we let regular people report what they see and hear to millions of others at the click of a button, no one will say the important things that need to be said. ${ }^{197}$

Although some people rightfully may feel that potential exposure discourages them from engaging in thoughtful debate, ${ }^{198}$ others may feel that potential exposure to a huge and immediate audience encourages sharing and debate. In fact, the inherent appeal of reaching such a broad audience likely is partly responsible for the meteoric rise in the use of social networking sites like Twitter and Facebook. On these sites and elsewhere, many individuals and groups seek out exposure and publicity for their ideas, rather than hide from them. Their reasons for doing so presumably range from egotism or vanity to more utilitarian reasons, such as the fact that speaking with someone else about your thoughts often improves them or the fact that making one's ideas known helps them to spread and gain favor. Regardless of the precise reason that people share ideas with others, it simply cannot be said with convincing authority that people generally need a public-yet-private incubator for their secret camaraderie and thoughts. ${ }^{199}$ Further, encouraging some people to pause before they share a thought may result in beneficial self-censorship. ${ }^{200}$ Thus, the

197 This argument also appears fundamentally flawed given that societies with less spatial privacy than we enjoy today apparently were able to think and write just fine. See Posner, supra note 16, at 407 (showing how "history does not teach that privacy is a precondition to creativity or individuality" because "these qualities have flourished in societies ... that had much less privacy than we in the United States have today").

${ }^{198}$ For example, the National Association for the Advancement of Colored People ("NAACP") famously argued that state-mandated disclosure of its membership lists would deter free enjoyment of the right to associate. NAACP v. Alabama, 357 U.S. 449, 462 (1958) ("It is hardly a novel perception that compelled disclosure of affiliation with groups engaged in advocacy may constitute as effective a restraint on freedom of association as the forms of governmental action in the cases above were thought likely to produce upon the particular constitutional rights there involved.")

199 See Posner, supra note 16, at 408-09. Daniel Solove has acknowledged that not all observation of one's thinking violates privacy. SOLOVE, UNDERSTANDING PRIVACY, supra note 17, at 86-87 ("Suppose I peek through your window and see that you are reading a book by Rousseau. I learned information about your consumption of ideas, which ultimately involves information about your identity. Without more details, however, it is hard to see how my snooping rises to the level of kidnapping.").

${ }^{200}$ See Danielle Keats Citron, Cyber Civil Rights, 89 B.U. L. REV. 61, 64-66 (2009) (documenting serious societal harms triggered by the "growth of anonymous online mobs that attack women, people of color, religious minorities, gays, and lesbians"); Lyrissa Barnett Lidsky, Anonymity in Cyberspace: What Can We Learn from John Doe?, 50 B.C. 
"thinking space" harm likely has been overstated and obscurity is not a necessary prerequisite for thought generation and association.

Various legal sources support the idea that the lack of public-yetprivate thinking space is an acceptable lack of obscurity rather than a serious harm. Perhaps the most recent and direct challenge to the idea that lack of thinking space in public is a serious harm comes from the Supreme Court in its recent decision, Doe v. Reed. ${ }^{201}$ In Doe, the Supreme Court held that state disclosure of the names and addresses of those who sign petitions in support of ballot referenda does not categorically violate the petition signers' First Amendment speech rights. ${ }^{202}$ In challenging the state statute requiring such disclosure, the signers of an anti-gay rights petition had argued that disclosing their names and addresses would chill speech, expose them to harassment and deprive them of privacy for their thoughts. ${ }^{203}$ This argument tracks that of privacy scholars who suggest that little to no obscurity will chill expression and thought development. ${ }^{204}$ The Doe v. Reed Court rejected this argument in an eight to one decision. ${ }^{205}$ Specifically, the Court found that the state law was a constitutional disclosure requirement that "may burden the ability to speak, but

L. REV. 1373, 1383 (2009) (labeling anonymity a "double-edged sword" because "it makes public discussion more uninhibited, robust, and wide-open than ever before, but it also opens the door to more trivial, abusive, libelous, and fraudulent speech"); $c f$. Lyrissa Barnett Lidsky \& Thomas F. Cotter, Authorship, Audiences and Anonymous Speech, 82 NOTRE DAME L. REV. 1537, 1573-74 (2007) (categorizing intrinsic benefits of anonymous speech).

201 Doe v. Reed, 130 S. Ct. 2811 (2010).

$202 \mathrm{Id}$. at 2815 . Before reaching its ultimate holding, the court determined that the signing of the petition was an expressive act, $i d$. at 2818 , and that disclosure requirements are subject to "exacting scrutiny," under which a "sufficiently important governmental interest" must be found. Id. In Doe, the Court ruled that the state's interest in preserving the integrity of its electoral process was sufficient. Id. at 2820.

${ }^{203} \mathrm{Id}$. at $\mathbf{2 8 2 0}$ (expressing concern that publicizing names and addresses provided a "blueprint for harassment and intimidation").

204 See supra notes $163-73$ and accompanying text (summarizing other scholars' suggestion that "thinking space" "underwrites the freedom to ... associate freely away from the glare of the public and without fear of reprisal").

205 Doe, $130 \mathrm{~S}$. Ct. at 2821 . The Court left the door open to an "as applied" challenge if petitioners could show that disclosure would, as applied to their particular case, cause enough harm to their First Amendment rights and personal safety. Id. (citations omitted). The holding also may be limited to actions that, like petition signing, have a "legal effect" similar to legislation. Id. at $2818 \mathrm{n} .1$. 
[does] not prevent anyone from speaking." ${ }^{206}$ In so finding, the court rejected a call for more privacy to facilitate activities deemed "intellectual,"207 at least when they have a lawmaking effect..208 Thus, in at least one context, the Supreme Court has considered and rejected the "lack of thinking space" privacy harm as a reason to restrict the exposure of truthful information.

Another legal reality that undermines the perceived lack of thinking space harm is the fact that there already are adequate methods to obtain legal protection for one's ideas and thoughts when necessary-namely, confidentiality or nondisclosure agreements. ${ }^{209}$ If secrecy of publicized thought truly is valuable enough to someone, it can be obtained via an express agreement prior to or after it is shared. ${ }^{2 \text { to }}$ Admittedly, obtaining such agreements involves various

\footnotetext{
${ }^{206}$ Id. at 2813-14 (quoting Citizens United v. FEC, 130 S. Ct. 876, 972 (2010)) (internal quotation marks omitted).
}

207 See Richards, supra note 61, at 1343 (suggesting that Supreme Court's alleged regard for intellectual privacy "holds a much greater degree of promise to better understand and resolve modern problems of privacy"); see also id. at 1343 (characterizing Warren and Brandeis's style of privacy as "a jurisprudential dead end" given conflict with First Amendment).

${ }^{208}$ Justice Scalia was most skeptical of the urged need for thinking space, stating as follows: "[H]arsh criticism, short of unlawful action, is a price our people have traditionally been willing to pay for self governance. Requiring people to stand up in public for their political acts fosters civic courage, without which democracy is doomed. For my part, I do not look forward to a society which, thanks to the Supreme Court, campaigns anonymously ... and even exercises the direct democracy of initiative and referendum hidden from. public scrutiny and protected from the accountability of criticism. This does not resemble the Home of the Brave." Doe, 130 S. Ct. at 2837 (Scalia, J., concurring) (citations omitted).

${ }^{209}$ See Daniel J. Solove \& Neil M. Richards, Rethinking Free Speech and Civil Liability, 109 CoLUM. L. REV. 1650, 1654 (2009) (describing use of confidentiality agreements to protect privacy) (citations omitted).

${ }^{210}$ In the absence of an express agreement, one may pursue a claim for breach of an implied duty of confidentiality in special circumstances, typically those involving a fiduciary relationship. See Peterson v. Idaho First Nat'l Bank, 367 P.2d 284 (Idaho 1961) (bank); Alberts v. Devine, 479 N.E.2d 113, 120 (Mass. 1985) (doctor); Rich v. N.Y. Cent. \& Hudson River R.R. Co., 87 N.Y. 382, 390 (1882) (lawyer); Wagenheim v. Alexander Grant \& Co., 482 N.E.2d 955, 961 (Ohio Ct. App. 1983) (accountant) (cited in Solove and Richards, supra note 209, at 1653 n.10 and accompanying text); see also Neil M. Richards \& Daniel J. Solove, Privacy's Other Path: Recovering the Law of Confidentiality, 96 GEO. L.J. 123, 157 (2007). Some have argued for extension of the implied duty of confidentiality to intimate private relationships and even to mere friends. See Ethan J. Lieb, Friends as Fiduciaries, 86 WASH. U. L. REv. 665, 668 (2009); Andrew J. McClurg, Kiss and Tell: Protecting Intimate Relationship Privacy Through Implied Contracts of Confidentiality, 74 U. CIN. L. REv. 887, 908 (2006); Andrew J. McClurg, Bringing Privacy 
transaction costs that may deter their use by some speakers. However, the ubiquitous availability of these legal options at least questions whether one absolutely needs a right to obscurity in order to develop thought. Accordingly, the "thinking space" harm likely has been overstated.

Sunshine laws and the benefits they have produced also call into question the need for privacy in public in order to facilitate thought development..211 One subset of sunshine laws generally requires governmental policy-related meetings to be open to the public and, in many cases, recorded, and even posted on a website. ${ }^{212}$ Similarly, many federal and state agencies require that people meeting with agency officials file a written notice describing what was discussed. ${ }^{213}$ Further, our nation has a history of open town meetings. 214 If those most directly responsible for making public policy decisions do not need privacy in public, then it is at least questionable whether those with a more remote role need such absolute privacy either.

Finally, much of the most justifiable fear regarding deprivation of thinking space is triggered only when the state is the one collecting the information or when the information collection is a constant, pervasive threat. ${ }^{215}$ The Obscurity Problem involves neither statebased nor constant surveillance. State surveillance is not directly involved because it is "Little Stranger," and not "Big Brother," that is

Law Out of the Closet: A Tort Theory of Liability for Intrusions in Public Places, 73 N.C. L. REV. 989, 1085-86 (1995).

${ }^{211}$ Many of these laws are so-named because Louis Brandeis, years after co-authoring The Right to Privacy, famously stated that "[s]unlight is said to be the best of disinfectants." LOUIS D. BRANDEIS, OTHER PEOPLE'S MONEY AND HOW THE BANKERS USE IT 62 (1914).

${ }^{212}$ See generally Daxton R. Stewart, Let the Sunshine In, Or Else: An Examination of the "Teeth" of State and Federal Open Meetings and Open Records Laws, 15 CoMM. L. \& POL'Y 265 (2010) (reviewing current status of sunshine laws at federal and state level including enforcement of and relief under such laws).

${ }^{213}$ See Heidi Reamer Anderson, Allocating Influence, 2009 UTAH L. REV. 683, 693-94 (collecting and summarizing agency rules regarding ex parte meeting notices).

214 See James Assaf, Note, Mr. Smith Comes Home: The Constitutional Presumption of Openness in Local Legislative Meetings, 40 CASE W. RES. L. REV. 227, 229-30 (1990) (documenting existence of sunshine laws in all fifty states requiring public access to local government meetings) (citations omitted).

215 See Richards, supra note 61, at 1351 (concluding that Brandeis was most concerned when privacy protection was threatened "principally [by] the state rather than the press"); but see Richards, supra note 61, at 1347-50 (documenting threats to "intellectual privacy"). 
collecting the information. ${ }^{216}$ When it is one's fellow citizens versus one's government officials doing the exposing, freedom of association and related issues are less of a concern.217 Second, arguments regarding surveillance's potential to chill expression are most persuasive when the surveillance is constant, versus intermittent. ${ }^{218}$ With the Obscurity Problem, surveillance is only occasional-and thus less of a threat to "thinking space."219

\section{B. BENEFITS OF EXPOSURE}

Just as we must "value privacy on the basis of the range of activities it protects" we also must consider the range of activities that protecting privacy would impede, i.e., the range of activities precluded by the privacy protections themselves. ${ }^{220}$ Although some scholars initially identify some of these benefits of exposure of public conduct or information, ${ }^{221}$ there is no comprehensive recognition, categorization, and aggregation of exposure's benefits in the privacy

${ }^{216}$ SOLOVE, UNDERSTANDING PRIVACY, supra note 17, at 133; see also Calo, supra note 176, at 1157-59 (reviewing Solove's references to Orwell and Kafka and suggesting that lack of privacy is better viewed as a contributor to societal harms than as a separate and distinct harm in itself).

217 They still remain a concern, however, given the government's reported use of privatelycollected information. See, e.g., Danielle Keats Citron \& Frank A. Pasquale III, Network Accountability for the Domestic Intelligence Apparatus, 62 HASTINGS L.J. 1441 (2011).

${ }^{218}$ See Calo, supra note 176 , at 1155 (suggesting that harm to privacy is best measured by multiplying "the degree of aversion" to the privacy intrusion by "the extent of [the] surveillance" and thus finding more harm when "the extent of the surveillance is enormous"); Josh Blackman, Omniveillance, Google, Privacy in Public and the Right to Your Digital Identity: A Tort for Recording and Disseminating an Individual's Image Over the Internet, 49 SANTA CLARA L. REV. 313, 327-34 (2009) (distinguishing harms from constant or ever-present surveillance, labeled "omniveillance," from lesser harms caused by occasional photographs).

${ }^{219}$ See SOLOVE, UNDERSTANDING PRIVACY, supra note 17, at 80-81 (discussing critics of the need for privacy for intellectual thought, including professors Hannah Arendt, Yao-Huai Lu, Richard Posner, and Richard Epstein).

220 Id. at 98-99.

${ }^{221}$ See id. at 123, 187 (acknowledging that identification "can reduce fraud and enhance accountability" and that "many privacy problems emerge as a result of efficacious activities, much as pollution is an outgrowth of industrial production"). 
literature. This section aims to fill that gap, beginning with a discussion of how exposure keeps government officials accountable. ${ }^{222}$

\section{GOVERNMENTAL ACCOUNTABILITY BENEFITS}

Daniel Solove claims that "dog poop girl would have been just a vague image in a few people's memories if it hadn't been for the photo entering cyberspace and spreading around faster than an epidemic."223 While this may be true, and may be deemed a net gain for society in that one instance, this does not mean that legally preventing or discouraging exposures of people's public behavior always results in a net gain for society. Recall the police brutality story from the Introduction involving Officer Walsh. Do we want events like that to be "vague image[s] in a few people's memories?"224 Of course not, because exposure of such images holds our government officials accountable, inspires public debate, and often leads to real policy changes. However, such benefits could be sacrificed in that situation and others like it if the person who videotaped the event did not post it to YouTube because he had a legal duty to protect the obscurity of Officer Walsh or of other people at the scene.

In trying to prevent harm suffered by the Dog Poop Girls of the world, we risk losing exposure of public behavior that should be further seen, heard, discussed, and addressed.225 Consider the many recent exposures of public officials at public events with other people nearby about which we may not have learned (or at least not seen) if the law protected people's obscurity in public:

\footnotetext{
${ }^{222}$ My categorization of these exposure benefits is a preliminary and perhaps less sophisticated attempt to do what Daniel Solove does for privacy harms in Understanding Privacy. Some of these benefits have speech elements and thus relate to many First Amendment arguments already made elsewhere. However, in the instant context of a pragmatic balancing of harms and benefits, it is more appropriate to discuss them in nonspeech terms, and perhaps mention the benefit's connection to the First Amendment in passing, just as pro-privacy scholars have done. In this respect, a benefit's relationship with the First Amendment increases its weight in the balance, but does not change its existence. Or, more concisely, one could consider the First Amendment as a thumb on the scale pushing down in favor of exposure.
}

223 SOLOVE, FUTURE OF REPUTATION, supra note 18 , at 8.

224 Id.

22.5 See Solove, supra note 1, at 973 ("Privacy impedes discourse, impairs autonomy in communication, and prevents accountability for one's conduct."). 
- Anti-gay comments made by candidate for New York Governor, Carl Paladino, in a meeting with religious leaders; 226

- Then Governor of South Carolina, Mark Sanford's, emails to the woman with whom he was having an extra-marital affair, and suggestions to his staff to account for his absences during these affairs by falsely stating that he was "hiking the Appalachian trail;"227

- The reference by George Allen, a candidate for Virginia's U.S. Senate seat, to an opponent's aide as "Macaca," which many interpreted as a racist statement equating the aide to a Macaque monkey;228

- Then Senate Majority Leader Trent Lott's birthday party statement suggesting that had civil-rights opponent and fellow Senator Strom Thurmond been elected president in 1948, on a pro-segregation platform, "we wouldn't have had all these problems over the years;" 229 and

${ }^{226}$ See Simone Weichselbaum \& Kenneth Lovett, Carl Paladino Accused of "Stunning Homophobia" After Anti-Gay Rant at Meeting with Jewish Leaders, N.Y. DAILY NEWS (Oct. 10, 2010, 5:10 PM), http://articles.nydailynews.com/2010-1010/local/27077787_1_civil-unions-gay-marriage-bill-gay-pride-parade.

${ }_{227}$ South Carolina Gov. Sanford Admits Extramarital Affair, CNN (June 24, 2009, 9:29 PM EDT),

http://www.cnn.com/2009/POLITICS/o6/24/south.carolina.governor/index.html.

${ }_{228}$ Tim Craig \& Michael D. Shear, Allen Quip Provokes Outrage, Apology, WASH. POST, Aug. 15, 2006, at A1, available at http://www.washingtonpost.com/wpdyn/content/article/2006/08/14/AR2006081400589.html.

229 Thomas B. Edsall, Lott Decried for Part of Salute to Thurmond, WASH. POST, Dec. 7, 2002, at A6, available at http://www.washingtonpost.com/ac2/wp-

dyn?pagename $=$ article\&contentId=A20730-2002Dec6\&not Found $=$ true. 
- Pictures posted on a website by Ninth Circuit Judge Alex Kozinski, depicting nude women painted to look like farm animals. ${ }^{230}$

Any one of these or similar exposures of public conduct or statements may have been precluded or at least "chilled" if the law recognized a right to obscurity. As a result, the helpful discussions and consequences these exposures motivated may not have occurred. Thus, there is a risk that providing a general right to obscurity would sacrifice significant governmental accountability benefits. In the end, "keeping pertinent information about public affairs out of the hands of the public is equally problematic," regardless of whether the information's source is a "citizen journalist" or a more traditional journalist. ${ }^{231}$

\section{BEHAVIORAL-IMPROVEMENT BENEFITS}

There also is significant value in continuing to apply the "no privacy in public" rule to everyone instead of applying it only to public officials. Just as the possibility of getting caught and punished acts deters crime, the possibility of getting exposed for public statements or behavior deters non-criminal but still objectively-undesirable behavior. ${ }^{232}$ Daniel Solove calls this type of exposure "norm policing," but this term is too pejorative for something that holds so much potential for benefitting society. Solove claims that "[w]e do not view the victims [of exposure] as blameworthy, and there is little social value in their suffering." 233 I disagree. This alleged suffering, in the form of lost dignity and lost obscurity, can lead to significant social value-and even save lives.

${ }^{230}$ Scott Glover, 9th Circuit's Chief Judge Posted Sexually Explicit Matter on His Website, L.A. TIMES, June 11, 2008, http://www.latimes.com/news/local/la-me-kozinski122008jun12,0,6220192.story.

${ }^{231}$ See Strahilevitz, Reunifying, supra note 35, at 12.

${ }^{232}$ See generally Paul H. Robinson \& John M. Darley, The Role of Deterrence in the Formulation of Criminal Law Rules: At Its Worst When Doing Its Best, 91 GEO. L.J. 949 (2003); SOLOVE, FUTURE OF REPUTATION, supra note 18, at 80-81, 92 ("Internet shaming has many benefits. Without shaming, people like the dog poop girl, the subway flasher, and the creep who harasses women in the street would often go unpunished. In a world of increasingly rude and uncivil behavior, shaming helps society maintain its norms of civility and etiquette.").

233 See Solove, supra note 42 , at 538. 
In Order Without Law, Robert Ellickson discussed the behavioral benefits of exposure. ${ }^{234}$ In a more recent and more specific study, Lior Jacob Strahilevitz demonstrated how additional exposure of people's reckless driving habits could reduce deaths on our highways-the number one cause of death among those aged fifteen to twentynine. ${ }^{235}$ Strahilevitz first showed how protecting motorist obscurity leads to rude, dangerous, and even life-threatening behavior. ${ }^{236} \mathrm{Next}$, he demonstrated how reducing driver obscurity through exposure by fellow citizens, and holding drivers accountable for their actions, has led to better and safer driving among some "exposed" groups and promises such benefits for society should the exposed groups be expanded. ${ }^{237}$ Indeed, Strahilevitz has shown how facilitating closeness and more "norm policing" may work better than the tort system itself as a way of curtailing and punishing bad behavior. ${ }^{238}$

Fewer people cutting us off or tailgating us may save lives. On a more abstract level, additional exposure and less obscurity, promise to increase happiness as well, on the highways and elsewhere. ${ }^{239}$ Fewer instances of other bad behavior may make life more enjoyable in various other contexts-primarily those in which obscurity authorizes

\footnotetext{
${ }^{234}$ Robert C. Ellickson, ORDER WITHOUT LAW: HOW NEIGHBORS SETTLE DISPUTES (1991); see Schwartz, supra note 7, at 1440-42 (explaining how Ellickson's work is pro-disclosure in part because it recognizes that "if the law can help reputational information circulate more freely, people will work harder to maintain the good opinion of others").

${ }^{235}$ Lior Jacob Strahilevitz, “How's My Driving” for Everyone (and Everything?), 81 N.Y.U. L. Rev. 1699, 1712 (2006).

${ }_{236}$ Strahilevitz, supra note 235, at 1705 (reviewing highway safety studies and concluding that " $[\mathrm{t}]$ he problems associated with urban and suburban driving are, by and large, creatures of motorist anonymity").
}

237 Id. at $1708-12$.

${ }^{238}$ Id. at $1724-26$.

${ }^{239}$ Strahilevitz demonstrated how exposure of drivers would increase happiness-an increase that likely would offset any other type of emotional harm suffered by the exposed drivers. Id. at 1702 ("Recent economic research has placed commuting at the very bottom of the happiness index, easily ranking as the least pleasurable major life activity in which Americans engage."); id. at 1729 ("While the costs associated with driver deaths and injuries are quite substantial, they may well be dwarfed by the sheer unhappiness associated with commutes to and from work."); id. at 1730 (discussing economists' studies regarding the value of happiness). 
and perhaps encourages objectionable behavior.240 For example, exposing poor tippers online has made servers who felt cheated feel better simply by reporting them; such exposure, in turn, may make patrons more courteous and more generous. Similarly, exposure of unruly hotel, sports stadium, or airport patrons could make visiting such places more enjoyable for all. ${ }^{241}$ If the potential for getting exposed for saying something extremely harmful to someone else actually changes someone's behavior-and prevents the harm that would have been caused-then this changed behavior is a benefit of the "no privacy in public" rule and is another benefit supporting the rule's retention.

\section{CRIMINAL DETERRENCE, REPORTING, AND INTEGRITY BENEFITS}

The fruits of exposure can be even more beneficial to society when it is a criminal act, versus happiness-reducing rudeness, that is subject to exposure. Louis Brandeis's suggestion that sunlight is the best disinfectant permeates popular culture and legal discourse. ${ }^{242}$ Often forgotten, however, is the second part of Brandeis's sunlight quote: and "electric light the most efficient policeman."243 As Brandeis suggested, exposure that leads to reduced obscurity for would-be criminals can be quite efficient at deterring crime, improving the integrity of the criminal justice system, and increasing the reporting of crimes, as discussed below.

As Daniel Solove has conceded, "social control can be beneficial . . . [f]or example, surveillance can serve as a deterrent to crime."244 In Great Britain, a government surveillance program using closed-circuit cameras (CCTV) reportedly has reduced street crimes in some areas by fifty percent or more. ${ }^{245}$ Although the Obscurity Problem includes,

\footnotetext{
240 See Cohen supra note 92, at 196 ("Maybe we don't want people to litter or spread germs, or to drive aggressively, and if the potential for exposure reduces the incidence of those behaviors, so much the better.").
}

${ }^{241}$ Strahilevitz, supra note 235, at 1763.

${ }^{242}$ See generally, Seth F. Kramer, Sunlight, Secrets, and Scarlet Letters: The Tension between Privacy and Disclosure in Constitutional Law, 140 U. PA. L. REV. 1 (1991).

243 BRANDEIS, supra note 211, at 92.

244 Solove, supra note 42 , at $493-94$.

245 See Christopher Slobogin, Public Privacy: Camera Surveillance of Public Places and the Right to Anonymity, 72 MISs. L.J. 213, 223 (2002); Shane McGlaun, London CCTV System Caught Over 2,500 Criminals in 2010, DAILYTECH (Dec. 28, 2010, 12:20 PM), 
by definition, only exposure by private persons versus governments, it is possible if not likely that private exposure has a similar, albeit less comprehensive, deterrent effect on crime as more comprehensive, government-led surveillance would have. Further, if Britain's CCTV is any indication, the crime-deterring effects come burdened with minimal "thinking space" or other harms. ${ }^{246}$ The increased feeling of safety then improves citizen well-being across the board, leading to additional self-liberty, not less. ${ }^{247}$

For the many crimes that will occur despite the presence of citizen journalists, exposure of public conduct likely will continue to assist in the reporting of crimes as well as in the apprehension and prosecution of the correct perpetrators. For example, citizens have used their cell phone cameras to expose drivers involved in "hit and run" accidents in ways that led to their eventual arrest. ${ }^{248}$ Similarly, some citizens reluctant to report crimes in-person have been willing to report crimes via cell phone text messages including photographs of the alleged perpetrators. ${ }^{249}$ Additionally, New York City residents now may report crimes via uploading their pictures or videos to a government website. 250 The freedom to expose others' public actions even

http://www.dailytech.com/London+CCTV+System+Caught+over+2500+

Criminals + in $+2010 /$ article20501.htm. But see Slobogin, supra, at 223-225 (sharing conflicting data regarding the effects of closed circuit monitoring on crime).

246 See Solove, Understanding PrIVACY, supra note 17, at 108 (acknowledging that Britain's CCTV, "is widely perceived as 'a friendly eye in the sky, not Big Brother but a kindly and watchful uncle or aunt"). I am unaware of any reports that the amount of productive thought coming out of Britain has declined since the time the cameras have been in use.

247 As one commentator has noted, "[a]rguments that claim that an open society must accept a certain amount of crime fail to recognize that individual liberties are often sacrificed when an individual's safety and security are forfeited." DENNIS BAILEY, THE OPEN SOCIETY PARADOX 71 (2004) (discussing how use of DNA could have caught a rapist and reduced other liberty-related harms such as those suffered by women who stayed indoors, bought guns, and endured needless fear and anxiety).

${ }^{248}$ See Ron Zurko, The Impact of Cell Phones on Crime, EHow,

http://www.ehow.com/about_5398414_impact-cell-phones-crime.html (last visited Jan. 4, 2012).

${ }_{249}$ See Cops Ask Public for Text-Message Crime Tips, FoxNEWs.COM (July 3, 2008), http://www.foxnews.com/story/o,2933,375486,0o.html.

${ }^{250}$ See Deborah Jian Lee, NYPD Calls on Citizens for Amateur Video Evidence, REUTERS (July 31,2008 ),

http://www.reuters.com/article/domesticnews/idUSN31366504200807 (cited in Josh Blackman, Omniveillance, Google, Privacy in Public, and the Right to Your Digital 
empowers some gutsy citizens to record and report the very criminals that have hurt them. ${ }^{251}$

More broadly, social networks, chock-full of reports regarding others' activities and whereabouts, have been and could continue to be harnessed to locate and track criminals or lost children. ${ }^{252}$ These same networks of citizen journalists and their exposures provide reliable and truthful alibis for the wrongly-accused, thereby improving the integrity of the system and ensuring that the right person eventually is caught.253 Further, replacing notoriously unreliable eyewitness testimony with more reliable evidence of exposures documented via still- and video-cameras also improves reliability. ${ }^{254}$ Ultimately, the presence and use of what amounts to millions of mobile, citizendirected security cameras could vastly improve the integrity and reliability of the criminal justice system, leading to improved safety and liberty for all citizens.

\section{EMOTIONAL AND THERAPEUTIC BENEFITS}

Although privacy scholars carefully have identified the emotional harms associated with the Obscurity Problem, they have not fully accounted for the emotional benefits associated with exposure. A

\footnotetext{
Identity: A Tort for Recording and Disseminating an Individual's Image Over the Internet, 49 SANTA CLARA L. REV. 313, 332 (2009)).

${ }_{251}$ See Police: Woman Took Pictures of Flasher, UPI (Jan. 15, 2009, 6:24 PM), http://www.upi.com/Odd_News/2009/01/15/Police-Woman-took-pictures-offlasher/UPI-52501232061864.
}

${ }^{252}$ See Taking Pictures of Police Officers in Public Is Not a Crime, PoliceCrimes.com (July 24, 2010, 7:36 PM), http://www.policecrimes.com/forum/viewtopic.php?f=26\&t=9148 ("Even in potential terrorism cases, the presence of lots of ordinary folks carrying cameras actually enhances public security. In the hours after the failed Times Square car-bomb attempt, officials ... sought out home movies shot by tourists.").

253 See, e.g., Damiano Beltrami, His Facebook Status Now? 'Charges Dropped,' NYTIMES.COM, FG/CH NEWS (Nov. 11, 2009, 11:10 AM), http://fortgreene.thelocal.nytimes.com/2009/11/11/his-facebook-status-now-charges-dropped (documenting use of Facebook posting as alibi and broader trend that "Web communications including photos and videos are providing evidence in legal battles ranging from murder trials to employment lawsuits").

254 The unreliability of traditional eyewitness testimony has been well-documented. See, e.g., Brandon L. Garrett, Judging Innocence, 108 CoLUM. L. REV. 55, 60 (2008) (showing that seventy-nine percent of rape or murder exonerees in expansive study were convicted based on incorrect eyewitness testimony). 
person who exposes another's public behavior via distributing a video or story online often does so because sharing her take on the behavior with others makes her feel better. ${ }^{255}$ Some describe the emotional benefit of sharing a story via a personal blog as providing "a new kind of intimacy, a sense that they are known and listened to."256 For intensely personal autobiographical speech, the emotional benefits to the speaker are even more pronounced and heart-felt. ${ }^{257}$ In fact, even the performance of "Numa Numa Guy" has been described as a reason to promote webcam recordings because his video exhibited pure emotional enjoyment of a song. ${ }^{25} 8$ Thus, silencing one person to protect the obscurity of another likely ends up sacrificing the emotional interests of the one silenced.

Exposure of public conduct also leads to emotional benefits for people similarly situated to the exposed person. When someone is exposed in public for supposedly shameful conduct-such as alcoholism-it often leads other people who engage in that conduct to feel connected and no longer alone. This powerful emotional benefit is why memoirs, a genre likely made impossible by a duty to protect others' obscurity, are so powerful. ${ }^{259}$ In turn, the readers of such truthful stories experience emotional benefits as well.

\footnotetext{
255 Posner, supra note 16 , at 400 (noting how “[a]nyone who has ever sat next to a stranger on a airplane or a ski lift knows the delight that people take in talking about themselves to complete strangers").
}

${ }_{256}$ See Emily Nussbaum, My So-Called Blog, N.Y. Times MAG., Jan. 11, 2004, at 33, available at $\mathrm{http} / /$ www.nytimes.com/2004/01/11/magazine/my-so-called-blog.html (reviewing phenomenon of adolescent blogs and concluding that "[e]xposure may be painful at times, but it's all part of the process of 'putting it out there,' risking judgment and letting people in").

257 See Sonja R. West, The Story of Me: The Underprotection of Autobiographical Speech, 84 WASH. U. L. REV. 905, 916-922 (2006) (carefully documenting the "American tradition of autobiographical speech" and "the modern trend of public self-disclosure"); see also Sonja R. West, The Story of Us: Resolving the Face-Off Between Autobiographical Speech and Information Privacy, 67 WASH \& LEE L. REV. 589 (2010) (proposing tort-based solution to the apparent conflict between valuing autobiographical speech and privacy).

${ }^{258}$ See Douglas Wolk, The Syncher, Not the Song: The Irresistible Rise of the Numa Numa Dance, THE BELIEVER, June/July 2006, available at http://believermag.com/issues/200606/?read=article_wolk ("Brolsma's video singlehandedly justifies the existence of webcams" because "[i]t's a movie of someone who is having the time of his life, wants to share his joy with everyone, and doesn't care what anyone else thinks."). Perhaps the positive feelings associated with exposure were part of his motivation for starting his own NumaNetwork on YouTube.

259 See West, Story of Me, supra note 257, at 919-20 (chronicling the recent increase in memoirs). 
Exposure even can help change a harmful social norm that wrongfully made a person feel "different" in the first place. For example, the "exposures" of certain celebrities as gay allegedly empowered others to come out and ultimately change the harmful social norm that made them feel ostracized. ${ }^{260}$ Even if the norm does not change, the exposure could lead to other emotional benefits such as a sense of community, relief, or forgiveness. ${ }^{261}$ Exposing people's public actions and statements also brings certain issues, previously hidden at the expense of a certain segment of society, into the public sphere where they can be debated and addressed..262 For example, some feminist scholars have argued that over-insistence on privacy kept many women's rights issues hidden from public scrutiny. In all of these ways, the increased pride, self-esteem, confidence and other emotional benefits likely offset dignity harms to the one being exposed or to people fearing exposure. ${ }^{263}$

\section{DECEPTION PREVENTION BENEFITS}

One reason some people vilify the Obscurity Problem is that they have something to hide and depend upon others' ignorance regarding this "something" in order to maintain their personal and professional relationships. ${ }^{264}$ Revealing this information may "correct misapprehensions that the individual is trying to exploit, as when a

${ }^{260}$ See SOLOVE, UNDERSTANDING PRIVACY, supra note 17 , at 144 (discussing Zimmerman and acknowledging that "more disclosures about people's private lives might change hypocritical social norms that societies proclaim in public but flout in private").

${ }^{261}$ See Posner, supra note 16, at 408 ("If ignorance is the prerequisite of trust, equally knowledge, which privacy conceals, is the prerequisite of forgiveness.").

${ }^{262}$ SOLOVE, UNDERSTANDING PRIVACY, supra note 17 , at $81-82$.

${ }_{263}$ See BAILEY, supra note 247, at 204 ("Interpersonal relationships will in fact be better if there is less of a concern for privacy. After all, forthrightness, honesty and candor are, for the most part, virtues, while hypocrisy and deceit are not.") (quoting Richard Wasserstrom).

264 RICHARd A. POSNER, THE ECONOMICS OF JUSTICE 260-61 (1981) (concluding that "[p] eople conceal past criminal acts not out of bashfulness but precisely because potential acquaintances quite sensibly regard a criminal past as negative evidence of the value of cultivating an acquaintance with the person"). Expanding this thought to non-criminal activities, people conceal past social behavior (e.g., a keg stand) not out of bashfulness but precisely because potential acquaintances (e.g., employers or first dates) quite sensibly regard a poor social choice in the past as negative evidence of the value of dating, employing, or spending time with such a person. 
worker conceals a serious health problem from his employer or a prospective husband conceals his sterility from his fiancée." ${ }^{265}$ Thus, exposing truthful facts about a person that he purposefully hides from others acts as a "deception prevention" device, which many view as a net benefit for society. ${ }^{266}$

Preventing deception leads to other societal benefits, both directly and indirectly, such as ensuring that one does not hire an irresponsible person to take care of one's children. ${ }^{267}$ Knowing more about someone also can help people make decisions based on real information rather than relying on inaccurate stereotypes. ${ }^{268}$ If we know more about people, and observe them benefitting society despite their past behavior, perhaps we will learn to be more forgiving and less judgmental. ${ }^{269}$ Legally barring or punishing the exposure of such information lets the deception and poor decision making continue in the interest of protecting a mythical right to obscurity. ${ }^{270}$

265 POSNER, supra note 264, at 233.

${ }^{266}$ Posner, supra note 16 , at 400 ; BAILEY, supra note 247 , at 184 (“[T] have, the less likely we are able to trust someone. Knowing something about a person helps you make a reasonable judgment about whether to trust him or her.") (discussing legal philosophy of Michael Froomkin).

${ }^{267}$ See FRED CATE, PRIVACY IN THE INFORMATION AGE 29 (1997) ("What parent would not want to know if her child's babysitter had been convicted for child abuse? Similarly, what storeowner would not want to know whether his physician had a history of malpractice? What man or woman would not want to know if a potential sexual partner had a sexually transmitted disease? What airline would not want to know if its pilots were subject to epileptic seizures? Yet the interest in not disclosing that information is precisely what privacy protects.").

${ }^{268}$ Strahilevitz, supra note 33 , at 1684-88 (suggesting ways in which reputational information can replace race as proxy and thus reduce discrimination based on race).

${ }^{269}$ In this way, a digital dossier, which Daniel Solove invites us to fear, is a good thing, not a bad thing. The dossier documents the positive as well as the negative. Perhaps as one philosopher suggests, it even would be quite liberating to not have to live two lives, one private, and one public. See Richard A. Wasserstrom, Privacy: Some Arguments and Assumptions, in PHILOSOPHICAL Dimensions OF PRIVACY, AN ANTHOLOGY 331 (Ferdinand D. Schoeman, ed., 1984) ("[An] emphasis upon the maintenance of a private side to life [leads to a] dualistic, unintegrated life that renders the individuals who live it needlessly vulnerable, shame ridden, and lacking in a clear sense of self [versus] the more open, less guarded life of the person who has so little to fear from disclosures of self . ...").

${ }^{270}$ Richard Posner equates some emphasis on privacy as fraud. Posner, supra note 16 , at 399 ("An analogy to the world of commerce may help to explain why people should not-on economic grounds, in any event-have a right to conceal material facts about themselves. We think it wrong (and inefficient) that the law should permit a seller in hawking his wares 


\section{Moving Towards the Proper Balance}

The purpose of Parts III.A and III.B was to begin aggregating the collective harms of the Obscurity Problem versus the collective benefits of exposing public conduct, pursuant to the balance described in Part II.B. In Part III.A, I showed that scholars appear to oppose the full democratization of exposure because they believe that it harms the emotional and intellectual interests of those exposed and of society as a whole. I then showed how these harms likely have been overstated due to the reliance on multiple assumptions that have gone unquestioned. For example, I showed how exposure harms often are fleeting, rather than permanent; how the potential for exposure has caused some people to think and speak more, not less; that the Supreme Court in Doe balanced interests and came down in favor of exposure; and how political activity has survived and flourished even when faced with exposure via sunshine laws.

Although further aggregation and discussion of benefits should be done before drawing ultimate conclusions, a preliminary balance is worth conducting. A good starting point for the balancing is to compare apples to apples-to compare emotional harms to emotional benefits. Parts III.A and III.B show that for every exposed or potentially exposed person emotionally harmed or threatened by an exposure, there is at least one person emotionally benefitted via the same exposure, whether it is the person doing the exposing, the person exposed, or the person receiving the exposed information. Assuming for balancing purposes that the number of people emotionally harmed or benefitted, and the degree to which they are so harmed or benefitted, is relatively equal, these harms and benefits likely balance each other out. ${ }^{271}$

The only harm then left on the side of changing the "no privacy in public" rule is the harm associated with intrusion into one's thinking space. ${ }^{272}$ Although it is difficult to quantify this harm, assigning it a precise value is not necessary. One also need not agree with me that this harm has been overstated due to certain faulty assumptions. ${ }^{273}$

to make false or incomplete representations as to their quality. But people 'sell' themselves as well as their goods.").

${ }^{271}$ Admittedly, this cannot be assessed as a perfect balance without a more detailed inquiry that assigns some value to each side in particular situations. Other interests not specifically mentioned such as those based on the First Amendment, also must be considered.

${ }^{272}$ See supra notes $160-72$ and accompanying text.

${ }^{273}$ See supra notes $173-94$ and accompanying text. 
Rather, one need only balance the thinking space value-whatever it may be-against the value of the many non-emotional benefits I described in Part III.B. ${ }^{274}$ For example, I showed how exposures consistent with the "no privacy in public" rule lead to more accountability for our government officials, increased enforcement of beneficial social norms that save lives, the tearing down of social norms that wrongfully oppress certain groups, more deterrence of criminal activity, increased ease of reporting criminal activity, more reliable eyewitness testimony, more accurate information about the people with whom we spend our valuable time and money, and the enjoyment of having one's voice heard by millions of others.

Although it likely is too early to make a definitive, pragmatic decision regarding the "no privacy in public" rule, these many benefits at least should make legal commentators pause before calling for its demise. Additional time and effort also should be directed toward examining the assumptions detailed in Part III.A to see if these alleged harms have a firm basis in reality. Only after taking those two stepsand doing so more evenhandedly-should anyone seriously consider changing the "no privacy in public" rule.

\section{SPECIAl CASES}

Although a pragmatic balance may favor retention of the "no privacy in public" rule in many instances, the balance may tip the other way in a small set of special cases distinguishable because they involve the exposure of a body part or bodily activity that society generally regards as "private" even when the person ventures into "public." This special category includes exposures such as publishing a photograph of a woman's bare bottom taken in a shopping center when a gust of air blows up her skirt, 275 publishing a photograph of a teenager's genitals taken during an athletic event, ${ }^{276}$ or publishing a photograph of someone going to the bathroom taken through the gap in a restaurant bathroom stall. 277 Under a strict application of the "no

274 See supra notes $215-67$ and accompanying text.

275 Daily Times Democrat v. Graham, 162 So. $2 d 474$ (Ala. 1964).

${ }^{276}$ McNamara v. Freedom Newspapers, Inc., 802 S.W.2d 901, 905 (Tex. App. 1991).

277 Autopsy photos, which often involve grisly bodily exposures, also likely would fall into this category. For a thorough discussion of why such photos deserve special privacy protection, see JON L. MILLS, PrIVACY: The LOST Right (2008). Prosser also acknowledged that "a difference may at least be found between a harmless report of a private wedding and the morbid publication of the picture of a deformed child." Richards \& Solove, supra 
privacy in public" rule that I defend above, these exposures would appear acceptable because the information collected and re-published initially was shared in a public place (i.e., a shopping mall, a soccer stadium or a restaurant).

A more careful inquiry, however, suggests that these bodily exposures instead deserve special treatment under the pragmatic balancing test given the comparatively greater harms and comparatively fewer benefits they trigger. ${ }^{278}$ On the harm side, exposures of one's body parts or bodily functions often have been considered particularly harmful to personal dignity, and thus worthy of special legal protection in other contexts. ${ }^{279}$ On the benefits side, the possible benefits flowing from such exposures are minimal because exposing someone's body parts or bodily functions generally does not improve governmental or personal accountability, deter crime, or prevent deception. ${ }^{280}$ As Richard Posner has stated, "because the individual's desire to suppress the photograph [of a body part] is not related to misrepresentation in any business or social market place, there is no basis for a presumption that the social value of disclosure exceeds that of concealment." 281

Consider the example of Robert, whose sexual preferences and behaviors were described by his one-time lover in her blog. ${ }^{282}$ Although having one's sexual preferences exposed to others is far from

note 17, at 10 (quoting WILLIAM L. PROSSER, HANDBOOK OF THE LAW OF TORTS (1st ed. 1941)).

${ }^{278}$ See also Lance Rothenberg, Comment, Peeping Toms, Video Voyeurs, and Failure of the Criminal Law to Recognize a Reasonable Expectation of Privacy in the Public Space, 49 AM. U.L. REV. 1127 (2000) (calling upon the criminal law to penalize voyeurs who surreptitiously record the private body parts of persons in public).

279 California and Louisiana already have adopted "video voyeur" statutes recognizing a privacy-based protection against recorded intrusions "under or through the clothing" of a person even if that person is in public. CAL. PENAL CODE $\S 647(\mathrm{j})(2)$ (West 2011); LA. REv. STAT. ANN. § 14:283(A)(1) (2011); see Rothenberg, supra note 278 (discussing California and Louisiana statutes and the real-life privacy violations that motivated them).

${ }^{280}$ Rather, the little information provided by exposing the "offensive or embarrassing characteristics of $[\mathrm{an}]$ individual" provides little to no discreditable information, and, thus, does not "serve the prevention-deception goal." Posner, supra note 16, at 413; see id. at 400 ("Some private information that people desire to conceal is not discreditable. In our culture, for example, most people do not like to be seen naked, quite apart from any discreditable fact that such observation might reveal.").

281 Id. at 414.

${ }^{282}$ Supra note 113 and accompanying text. 
ideal for most people, the pragmatic balance would shift significantly in Robert's favor should Ms. Cutler have sought to describe or publish a photograph of Robert's genitals. The latter exposure likely would fall into the special cases category described here because the benefits to society of sharing the information would be exceptionally low (knowing precisely what Robert's genitals look like does not help one judge whether he is a good or bad person), while the harms to Robert's dignity would be exceptionally high (knowing that anyone, anywhere can pull up a picture of one's genitals could be particularly harmful to one's dignity and other emotional interests). ${ }^{283} \mathrm{~A}$ similar approach could be used to justify restrictions on publishing the name of a rape victim or on publishing autopsy photos because such exposures "cause[] distress to the victim's family while providing no information useful to people contemplating transactions with her (since she was dead) or with her family." 284 Ultimately, these body-focused exposures likely are less worthy of protection because they provide no useful reputational information regarding the individual exposed, and therefore are distinguishable from all other types of exposures of information shared in public.

\section{CONCLUSION}

The rhetoric regarding technology's assault on privacy has peaked at predictable points in time, most often when appreciation of a certain technology's beneficial uses has not yet caught up to the fears regarding its negative uses. ${ }^{285}$ One common tactic is to describe technology as a new, more harmful type of privacy invasion, thus

\footnotetext{
283 Posner, supra note 16, at 414. Similarly, consider the exposure of Dog Poop Girl's behavior-her refusal to clean up her dog's excrement on a subway train-versus an exposure involving Dog Poop Girl's own body parts or bodily functions. Publishing a photograph of Dog Poop Girl's bare bottom taken while she was going to the bathroom is inherently different than publishing the photograph of her refusing to clean up her dog's excrement; the former "could convey no information enabling her friends and acquaintances to correct misapprehensions about her character which she might have engendered" while the latter would help friends and acquaintances to decide whether she was a good, respectful person or not. Id.

284 Id. at 416.

${ }^{285}$ Fears about online privacy are particularly amusing to some critics who work in the technology business. See, e.g., BAILEY, supra note 247, at 137 ("You can go and find a mailbox right now, open the door to a tin box, tin door, no lock, with unencrypted information in English, sealed in a paper-thin envelope with spit, yet people are worried about online privacy.") (quoting Scott McNealy of Sun Microsystems).
} 
inspiring fear. "We shall soon be nothing but transparent heaps of jelly to each other," warned an interviewer of the inventor of a wireless signaling device capable of penetrating walls. ${ }^{286}$ "[T] he latest advances in photographic art have rendered it possible to take pictures surreptitiously," gasped Warren and Brandeis.287 Fear of these supposed harms then is used to justify some type of new legal restriction or remedy. ${ }^{288}$ At present, the fear is inspired by stories of lives permanently and irreversibly scarred by public information being shared with millions and associated warnings that "you, too, could be Dog Poop Girl, and have your life ruined" due to a short lapse in judgment. ${ }^{289}$ The new legal restriction or remedy demanded is a supposedly necessary change to the "no privacy in public" rule in order to protect people's obscurity.

Critics of the "no privacy in public" rule suggest that its time has passed and that one now needs some amount of privacy in public-in other words, a right to obscurity-in order to function in society. However, as the initial harms versus benefits balance detailed above shows, the "no privacy in public" rule likely remains valid, useful, and beneficial to society, even one as technologically-advanced as our own, in all but a very few special cases. This is because the current and future lack of a right to obscurity leads to many positive societal benefits, including accountability for our public officials and

\footnotetext{
${ }^{286}$ Science, The Academy, Vol. 50, p. 569, Dec. 19, 1896-No. 1285 (cited by Virginia Postrel, No Telling, REASON, June 1998).

${ }^{287}$ See Warren \& Brandeis, supra note 36 , at 211. "Instantaneous photographs . . . have invaded the sacred precincts of private and domestic life; and numerous mechanical devices threaten to make good the prediction that 'what is whispered in the closet shall be proclaimed from the house-tops."' Id. at 195; see also Warren \& Brandeis, supra note 36, at 196 (" $[M]$ odern enterprise and invention have, through invasions upon his privacy, subjected him to mental pain and distress, far greater than could be inflicted by mere bodily injury."). Even the concept of the white pages in the phone book once triggered irrational privacy fears. BAILEY, supra note 247 , at $172-73$.
}

${ }^{288}$ As Coleridge famously stated, "In politics, what begins in fear usually ends in folly."

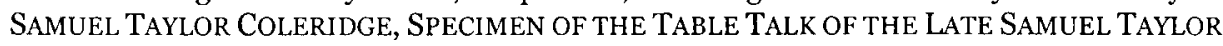
COLERIDGE 111 (1836).

${ }^{289}$ See, e.g., SOLOVE, FLTURE OF REPUTATION, supra note 18, at 48 ("Whether you like it or not, whether you intend it or not, the Internet can make you an instant celebrity. You could be the next Star Wars Kid."); SOLOVE, THE FUTURE OF REPUTATION, supra note 18, at 2 ("Like the dog poop girl, you could find photos and information about yourself spread around the Internet like a virus."); Solove, supra note 1, at 969 ("Without warning, anyone can broadcast another's unguarded moments or times of youthful awkwardness to an audience of millions."). 
ourselves, better crime prevention and reporting, and more information about the people with whom we engage in important personal and business transactions. Ultimately, the balance is likely to show that a potential loss in obscurity is a small price to pay for these benefits, and that the "no privacy in public" rule generally remains valid. At the very least, before we decide to restrict the flow of truthful, public information in the interest of protecting Dog Poop Girl's mythical right to obscurity, we need to better understand what it is we are sacrificing by doing so. 